\title{
Borneo coral reefs subject to high sediment loads show evidence of resilience to various environmental stressors
}

\author{
Nicola Browne ${ }^{1,2}$, Christina Braoun ${ }^{3}$, Jennifer McIlwain ${ }^{\text {Corresp., 1, }}{ }^{2}$, Ramasamy Nagarajan ${ }^{4}$, Jens Zinke ${ }^{1,2,3,5,6,7}$ \\ ${ }^{1}$ Molecular and Life Sciences, Curtin University, Perth, WA, Australia \\ 2 Curtin Sarawak Research Institute, Curtin University, Miri, Sarawak, Malaysia \\ 3 Department of Biology, Chemistry and Pharmacy, Freie Universität, Berlin, Germany \\ 4 Department of Applied Geology, Curtin University, Miri, Sarawak, Malaysia \\ ${ }^{5}$ School of Geography, Geology and Environment, Centre for Palaeobiology, University of Leicester, Leicester, United Kingdom \\ ${ }^{6}$ Australian Institute of Marine Science, Townsville, WA, Australia \\ ${ }^{7}$ Institute for Geosciences, Section Paleontology, Freie Universität, Berlin, Germany \\ Corresponding Author: Jennifer Mcllwain \\ Email address: jennifer.mcilwain@curtin.edu.au
}

For reefs in SE Asia the synergistic effects of rapid land-development, insufficient environmental policies and a lack of enforcement has led to poor water quality and compromised coral health from increased sediment and pollution. Those inshore turbid coral reefs, subject to significant sediment inputs, may also inherit some resilience to the effects of thermal stress and coral bleaching. We studied the inshore turbid reefs near Miri, in northwest Borneo through a comprehensive assessment of coral cover and health in addition to quantifying sediment-related parameters. Although Miri Reefs had comparatively low coral species diversity, dominated by massive and encrusting forms of Diploastrea, Porites, Montipora, Favites, Dipsastrea and Pachyseris, they were characterised by a healthy cover ranging from $22-39 \%$. We found a strong inshore to offshore gradient in hard coral cover, diversity and community composition as a direct result of spatial differences in sediment at distances $<10 \mathrm{~km}$. As well as distance to shore, we included other environmental variables like reef depth and sediment trap accumulation and particle size that explained $62.5 \%$ of variation in benthic composition among sites. Miri's reefs showed little evidence of coral disease and relatively low prevalence of compromised health signs including bleaching (6.7\%), bioerosion (6.6\%), pigmentation response $(2.2 \%)$, scars ( $1.1 \%)$ and excessive mucus production $(0.5 \%)$. Tagged colonies of Diploastrea and Pachyseris suffering partial bleaching in 2016 had fully (90-100\%) recovered the following year. There were, however, seasonal differences in bioerosion rates, which increased five-fold after the 2017 wet season. Differences in measures of coral physiology, like that of symbiont density and chlorophyll a for Montipora, Pachyseris and Acropora, were not detected among sites. We conclude that Miri's reefs may be in a 
temporally stable state given minimal recently dead coral and a limited decline in coral cover over the last two decades. This study provides further evidence that turbid coral reefs exposed to seasonally elevated sediment loads can exhibit relatively high coral cover and be resilient to disease and elevated sea surface temperatures. 
1 Borneo coral reefs subject to high sediment loads show evidence of resilience to various

2 environmental stressors

3

4

Nicola Browne ${ }^{1,2}$, Christina Braoun ${ }^{3}$, Jennifer McIlwain ${ }^{1,2}$, Ramasamy Nagarajan4, Jens Zinke $e^{1,2,3,5,6}$

${ }^{1}$ Molecular and Life Sciences, Curtin University, Perth, WA, Australia

${ }^{2}$ Curtin Sarawak Research Institute, Curtin University, Malaysia

${ }^{3}$ Department of Biology, Chemistry and Pharmacy, Freie Universität Berlin, Berlin, Germany

${ }^{4}$ Department of Applied Geology, Curtin University Malaysia, Miri, Sarawak, Malaysia

${ }^{5}$ School of Geography, Geology and the Environment, Centre for Palaeobiology, University of Leicester, Leicester, LE1 7RH, United Kingdom

${ }^{6}$ Australian Institute of Marine Science, Townville, Australia

Corresponding Author:

Jennifer McIlwain ${ }^{1}$

5 Rue du Gouverneur Guyon, Noumea, 98800, New Caledonia

Email address: jennifer.mcilwain@curtin.edu.au

\section{ABSTRACT}

For reefs in SE Asia the synergistic effects of rapid land-development, insufficient environmental policies and a lack of enforcement has led to poor water quality and compromised coral health from increased sediment and pollution. Those inshore turbid coral reefs, subject to significant sediment inputs, may also inherit some resilience to the effects of thermal stress and coral bleaching. We studied the inshore turbid reefs near Miri, in northwest Borneo through a comprehensive assessment of coral cover and health in addition to quantifying sediment-related parameters. Although Miri Reefs had comparatively low coral species diversity, dominated by massive and encrusting forms of Diploastrea, Porites, Montipora, Favites, Dipsastrea and Pachyseris, they were characterised by a healthy cover ranging from $22-39 \%$. We found a strong inshore to offshore gradient in hard coral cover, diversity and community composition as a direct result of spatial differences in sediment at distances $<10 \mathrm{~km}$. As well as distance to shore, we included other environmental variables like reef depth and sediment trap accumulation and particlesize that explained $62.5 \%$ of variation in benthic composition among sites. Miri's reefs showed little evidence of coral disease and relatively low prevalence of compromised health signs including bleaching $(6.7 \%)$, bioerosion $(6.6 \%)$, pigmentation response $(2.2 \%)$, scars $(1.1 \%)$ and excessive mucus production (0.5\%). Tagged colonies of Diploastrea and Pachyseris suffering partial bleaching in 2016 had fully $(90-100 \%)$ recovered the following year. There were, however, seasonal differences in bioerosion rates, which increased five-fold after the 2017 wet season. Differences in measures of coral physiology, like that of symbiont density and chlorophyll a for Montipora, Pachyseris and Acropora, were not detected among sites. We conclude that Miri's reefs may be in a temporally stable state given minimal recently dead coral and a limited decline in coral cover over the last two decades. This study provides further 
44 evidence that turbid coral reefs exposed to seasonally elevated sediment loads can exhibit 45 relatively high coral cover and be resilient to disease and elevated sea surface temperatures.

46

\section{INTRODUCTION}

48 Turbid reefs are commonly regarded as marginal reefs living near their environmental limits 49 (Kleypas et al., 1999; Guinotte et al., 2003; Perry and Larcombe, 2003; Palmer et al., 2010; 50

Goodkin et al., 2011). As such, these reefs are traditionally perceived to be in a reduced health status (Kleypas, 1996; Kleypas et al., 1999) and more sensitive to rising sea surface temperatures (SST; Nugues and Roberts, 2003; Crabbe and Smith, 2005; Fabricius, 2005; Woolridge, 2008). Yet, there is growing evidence that turbid reefs may actually be more resilient to future climate change effects (Goodkin et al., 2011; Morgan et al., 2017) and serve as refugia for surviving corals (Cacciapaglia and van Woesik, 2015; 2016; Morgan et al., 2016). This has been demonstrated on turbid reefs that experience significant sediment and nutrient inputs, yet are still characterized by high coral cover, low bleaching, and rapid recovery rates from bleaching and cyclonic events (Larcombe et al., 2001; Browne et al., 2010; Richards et al., 2015; Morgan et al., 2016). Studying the level of resilience and survival of turbid reefs in different environmental settings will provide clearer insights into the future of reefs subject to climate change (Guinotte et al., 2003; Hennige et al., 2010; Richards et al., 2015).

Despite elevated resilience to naturally turbid conditions, many inshore turbid reefs face threats from local pressures, largely related to declining water quality and increased sediment input. In South East (SE) Asia, 95\% of reefs are threatened from local sources and, therefore, are regarded as the most endangered reefs globally (Burke et al., 2011). From the 1980's to early 2000's hard coral cover on reefs in SE Asia declined from $45 \%$ to $22 \%$ at an average rate of $2 \%$ loss per year (Bruno and Selig 2007). Most SE Asian reefs are located in close proximity to countries with rapidly emerging economies and fast population growth (Wilkinson, 2006; Burke et al., 2011; Heery et al., 2018). They are further characterised by poorly developed environmental policies, inadequate regulation, lack of enforcement, a shortage of institutional and technical capacity, insufficient community support and involvement, and conflicts and tensions between stakeholders (Fidelman et al., 2012). The synergistic effects of these factors has led to poor water quality on many inshore reefs via pollution and sediment input derived by rapid land development, and over-fishing activities (McManus, 1997; Wilkinson, 2006). As a consequence, 
76 sedimentation rates are high with SE Asian coastal systems experiencing the highest siltation

77 loads globally (Kamp-Nielsen et al., 2002; Syvitski et al., 2005).

78

79 Nearshore coral reefs along the north central section of Sarawak, on the island of Borneo, are 80 highly diverse with an estimated 518 fish species (Shabdin, 2014) and 203 hard coral species 81 from 66 genera (Elcee Instumentation, 2002). Sarawak is a deforestation hotspot with only 3\% of 82 its forest cover intact (Bryan et al., 2013). Ongoing deforestation and poor land use practices are 83 a growing threat for these biological diverse reefs that also support local fisheries and an 84 expanding dive tourism industry (Elcee Instumentation, 2002). As such, in 2007 a marine park 85 (the Miri-Sibuti Coral Reef National Park; MSCRNP) that covered 11,020 $\mathrm{km}^{2}$ was established 86 to promote and protect 30 coral reefs adjacent to Miri, the second largest town in Sarawak. In 87 2001, a broad assessment of coral reef health within the park indicated that live coral cover was 88 approximately $35-50 \%$ and recently dead coral cover was $0.5 \%$ (Elcee Instumentation, 2002).

89 Subsequent Reef Check surveys in 2010 and 2014 concluded these same reefs were experiencing 90 multiple stressors, but were in 'fair' condition ( 40\% hard coral cover; Reef Check, 2010;2014). 91 However, despite these surveys there is limited quantitative data on coral health and biodiversity 92 (Shabdin, 2014), and more importantly no comprehensive assessment of environmental drivers 93 of reef health. For example, the Baram River (10 km north of the reef complex), is known to 94 discharge $2.4 \times 10^{10} \mathrm{~kg} \mathrm{yr}^{-1}$ of sediments into the coastal zone (Nagarajan et al., 2015), such that 95 sediment and nutrient influx are considered to be the greatest threat to these poorly studied reefs 96 (Pilcher and Cabanban, 2000; Ferner, 2013; Shabdin, 2014). Without thoroughly quantifying 97 sediment impacts on corals, no conclusions can be made on coral tolerance levels, the drivers of 98 community composition and future resilience to both local and global pressures. Given the 99 Baram River delta is in a destructive phase due to rising sea level (Lambiase et al., 2002), 100 together with the increased frequency and intensity of rainfall events and plans for future 101 modification of both the river and adjacent land development (Nagarajan et al., 2015), it is likely 102 that threats from sediments will only increase.

103

104 The reefs within the MSCRNP provide a valuable opportunity to address several knowledge gaps 105 on turbid coral reef health and their potential resilience to local and global threats. The last 106 comprehensive assessment of coral cover on Miri's reefs was in 2001 (Elcee Instumentation, 
107 2002), with no assessments of coral taxa health and disease for any Sarawak reef recorded to

108 date. In particular, coral disease studies are rarely undertaken on SE Asian reefs largely due to a 109 lack of resources and expertise (Green and Bruckner, 2000; Raymundo et al., 2005; Heintz et al., 110 2015). The lack of quantitative data on the health and stability (as defined by resistance, 111 resilience and maintenance of key functional groups) of these reefs coupled with ongoing 112 unsustainable land use practices in Sarawak, raises concerns over their long-term viability. This 113 is of particular concern as Sarawak reefs have been estimated to provide 6 million AUD per year 114 in tourism and 13.5 million AUD from fisheries (Elcee Instumentation, 2002). We argue there is 115 an urgent need for a comprehensive assessment of coral cover and health measured alongside 116 key environmental and sediment-related parameters. The key objectives of this study therefore 117 are to: 1) quantify benthic cover and health, 2) compare the prevalence of impaired health in the 118 dominant coral species, and 3) identify key parameters related to sediment delivery that are 119 associated with benthic cover and health along an inshore to offshore gradient. These data will 120 improve our understanding of turbid coral reefs composition and potential resilience to both local 121 and global stressors, and promote current management strategies that aim to protect inshore 122 turbid reefs from future changes to land use.

\section{MATERIALS \& METHODS}

\section{Study sites}

The study was conducted on three low profile submerged patch reefs (Eve's Garden, Anemone Garden and Siwa Reef) in the MSCRNP (Fig. 1). These sites were of a comparable depth (5-15 $\mathrm{m})$ and size $\left(<0.11 \mathrm{~km}^{2}\right)$, and do not have the typical windward-leeward zonation patterns. As such, benthic composition over the reefs are comparatively homogenous. Eve's Garden (EG) is a shallow inshore reef close to shore $(7.3 \mathrm{~km})$ with a coral community dominated by plate and massive corals such as Pachyseris sp. and Porites sp. (Ferner, 2013). Anemone Garden (AG) is further offshore $(11.7 \mathrm{~km})$ and consists of a considerable density of anemone colonies, with plating forms of Acropora sp. and exceptionally large massive Porites sp. and Diploastrea sp. colonies (1-5 m length). Siwa Reef (SW) situated further to the south is the most biologically diverse of the studied reefs consisting of encrusting and massive coral forms (Ferner, 2013). 
137 kg.year-1; Nagarajan et al., 2015) and Miri River mouths, located to the north of EG (10 km from 138 Miri river and $30 \mathrm{~km}$ from Baram river).

139

140 Physical (temperature, light, turbidity and sediment trap accumulation) and biological (benthic 141 cover, coral health) data were collected at the end of the dry season ( $15^{\text {th }}$ September to $20^{\text {th }}$ 142 October 2016) and during the wet season (11 $1^{\text {th }}$ May to $3^{\text {rd }}$ June 2017). At each of the three reefs, 143 six replicate line transects $(20 \mathrm{~m})$, separated by $20 \mathrm{~m}$ intervals to ensure independence were run 144 across the reef surface $(E G=8-12 \mathrm{~m} ; \mathrm{AG}=10-14 \mathrm{~m} ; \mathrm{SW}=8-14 \mathrm{~m})$. These reefs are not 145 characterized by typical windward and leeward reef edges, but are low profile patch reefs where 146 the majority of the reef sits in one relatively flat plane, sloping gently on all sides to the sea floor. 147 As such, all transects were laid out along the same axis across the flat section of each reef.

\section{Physical data collection}

150 Seasonal changes in light (measured with Photosynthetic Irradiance Recording System by 151 Odyssey, New Zealand) and temperature (measured with HOBO Pro V2 loggers, Australia) were recorded every 10 minutes from September 2016 for 9 months (temperature at EG and AG) and 12 months (light at EG). To capture changes in suspended sediment loads over a tidal cycle, turbidity loggers were deployed (in a horizontal position) for two weeks at the end of the 2016 dry season (September; EG and SW) and end of the 2017 wet season (May; EG; AQUA logger 210/310TY, Aquatech, UK). Data on cloud cover, rainfall and wind speed over the period from October 2016 to October 2017 was retrieved from the online database World Wide Weather (2017).

159

To assess small-scale spatial variation in sediment trap accumulation, four sediment traps per three transects ( 8 traps in total per reef) were deployed at each reef in September 2016 to collect sediments during the NE monsoon. Each trap consisted of 3 cylindrical PVC plastic containers (diameter of $7.6 \mathrm{~cm}$ by $15 \mathrm{~cm}$ high) attached to a metal rod positioned $30 \mathrm{~cm}$ above the substrate 164 (Storlazzi et al., 2011). The traps remained in-situ until May 2017. To determine if trapped sediments were from local resuspension or transported on to the reef, $500 \mathrm{~g}$ of benthic sediment at the base of each trap was sampled. The content of each trap was emptied into a labelled 
167 plastic bag and stored at $-20^{\circ} \mathrm{C}$ until further analysis at the Curtin University Sarawak Laboratory 168 facilities (Laboratory SK2 204), Malaysia.

169

170 Sediment samples were analysed for weight and particle size characteristics. Frozen samples 171 were thawed and allowed to settle overnight. Water remaining on the surface was filtered $(0.45$ $172 \mathrm{~nm}$ filter paper) to capture the fine suspended sediments. The sediments (washed, settled and 173 filtered) were oven-dried at $60{ }^{\circ} \mathrm{C}$ for $2-3$ weeks and weighed to the nearest $0.001 \mathrm{~g}$.

174 Sedimentation accumulation rate $\left(\mathrm{g} \mathrm{cm}^{2}\right.$ day $\left.^{-1}\right)$ was calculated as the weight of sediment trapped 175 (g) divided by the number of days the trap was deployed and the surface area of the trap $\left(\mathrm{cm}^{2}\right)$. 176 For the grain size analysis, the settled dry sediments were manually homogenized and weighed 177 before sieving. The sediments were homogenized using a pestle and mortar given the sediments 178 were mostly sand and loosely aggregated. Sediments were separated into 5 class fractions $(>1$ 179 $\mathrm{mm}, 500$ to $<1000 \mu \mathrm{m}, 250$ to $<500 \mu \mathrm{m}, 125$ to $<250 \mu \mathrm{m}$ and 63 to $125 \mu \mathrm{m}$ ) by placing the sieve stack on a mechanical shaker for 20 minutes. Each of the 5 sediment fractions were weighed to 181 the nearest $0.001 \mathrm{~g}$.

182

\section{Biological data collection}

\section{In water data collection}

The benthic cover and coral diversity (to genus level) in September 2016 were assessed using the photographic transect method (Bégin et al., 2013). Photographs were taken using a Canon Powershot G7 mark II digital camera at a fixed height of $0.75 \mathrm{~m}$ above the transect line every 1 $\mathrm{m}$ along the transect $(\mathrm{n}=21)$. Photographs $\left(0.5 \mathrm{~m}^{2}\right)$ were analysed in Coral Point Count (CPCe) with a uniform grid of 25 points to calculate benthic cover for each of 8 categories (hard coral, soft coral, recently dead coral, turf algae, macroalgae, crustose coralline algae, sponge, abiotic substrate) (CPCe; Kohler and Gill, 2006). Recently dead coral ( $<1 \mathrm{yr}$ ) was considered to include dead coral that had visible corallites and limited algae growth. The hard coral category was further subdivided into 38 genera common to the Indo-Pacific region according to Kelley (2009).

To assess seasonal fluctuations in coral reef health, signs of compromised health (disease, bleaching, bioerosion, pigmentation response, excessive mucus production, scars) were recorded in September 2016 and May 2017. The belt transect methodology was used to cover a wider area 
198 along the transect line via a zig-zag pattern $1 \mathrm{~m}$ either side of the transect line $\left(40 \mathrm{~m}^{2}\right.$ for each 20 $199 \mathrm{~m}$ transect). Coral colonies within each belt transect were identified to genus level and classified 200 as either healthy or affected by an impaired health sign (Beeden et al., 2008). Signs of bioerosion 201 included the presence of organisms such as Christmas tree worms, boring bivalves and sponges, 202 and bleaching was further subdivided into whole, partial, focal and non-focal bleaching (as 203 defined in Beeden et al., 2008). To determine if bleached corals recovered or died, 14 coral 204 colonies from EG and SW in both sampling seasons that showed signs of bleaching were tagged 205 and photographed (4 Diploastrea sp., 6 Pachyseris sp., 4 Porites sp.). The percentage of 206 bleached tissue was assessed from scaled photographs using CPCe software $(1=$ normal, $2=$ pale, 207 $3=0-20 \%, 4=20-50 \%, 5=50-80 \%$ and $6=80+\%$ bleached). While this is a low sample size, the

208 data is included to provide further insight into the recovery potential of corals on these reefs.

209

\section{Symbiont density and chlorophyll a analysis}

211 In May 2017, fragments of three coral genera (Montipora sp., Pachyseris sp. and Acropora sp.) 212 were collected from EG, AG and SW for chlorophyll $a$ and symbiont density analysis. Higher 213 chlorophyll $a$ and symbiont densities are typically recorded on turbid reefs (Browne et al., 2015) 214 as this increases the coral's ability to photosynthesis under low light levels as they acclimate to 215 suspended sediments (Hennige et al., 2010). Fragments (5-10 cm for branching corals and $\sim 10 \mathrm{x}$ $21610 \mathrm{~cm}$ for foliose corals) were collected using cutters and placed in plastic bags. Samples were 217 placed on ice during transportation back to the laboratory where they were stored at $-80{ }^{\circ} \mathrm{C}$ until 218 further analysis. Symbiont density and chlorophyll $a$ content were quantified following the 219 removal of coral tissue from the skeleton. The protocol for extracting tissue was adapted from 220 Ben-Haim et al. (2003) (Supplementary material).

221

\section{Statistical analysis}

223 Univariate statistical analysis was conducted in R Studio Desktop version 1.1.383. Prior to 224 analysis, normal distribution and homogeneity of variances were checked using the Shapiro Wilk 225 test and the Levene's test, respectively. To assess if there were significant differences in benthic 226 cover (hard coral, soft coral, algae) and diversity among sites a one way analysis of variance 227 (ANOVA, $n=6, \alpha=0.05$ ) was used followed by a Tukey HSD post-hoc test (Bonferroni 228 method), if necessary. Significant differences in the prevalence of compromised health signs 
229 (bleaching, bioerosion, mucus production, pigmentation and scars) among sites and between 230 seasons were identified for both total hard coral cover and for the most abundant coral genera 231 (Porites, Pachyseris, Montipora, Diploastrea, Acropora) using a Full Factorial ANOVA (FF 232 ANOVA, $n=6, \alpha=0.05$ ) and a Tukey HSD post- hoc test. If required, a $\log 10$ transformation 233 was carried out for datasets to meet homogeneity of variance. However, as the bleaching 234 recovery was assessed using a scale, these data were tested using a Wilcoxon test to determine if 235 there had been a significant recovery in tagged coral colonies between years. To determine differences in physiology (chlorophyll $a$ content and zooxanthellae density) between the three coral genera sampled (Acropora $\mathrm{n}=17$, Pachyseris $\mathrm{n}=13$, Montipora $\mathrm{n}=15$ ) and across sites, a non-parametric Kruskal Wallis test was performed. Furthermore, to evaluate cell health differences between the three genera and among reefs, the percentage of cells from each grade were compared using the Kruskal-Wallis test. Differences in sediment trap accumulation rates was tested among reefs (Kruskal - Wallis). In addition particle size characteristics (median, fine/course fraction) among reefs, and between the trapped sediments and the benthic sediments were also tested (FF ANOVA, $\mathrm{n}=18$ ).

244

Permutational multivariate analysis was conducted in PRIMER-7 version 7.0.13. A Distancebased Linear Model (DISTLM) was used to determine how much of the variation in community assemblage (hard coral cover $=\mathrm{HCC}$, soft coral cover $=\mathrm{SCC}$, algae, recently dead coral cover=DCC, H' index, number of coral genera) among transects and reefs was driven by depth, distance from the two nearby river mouths, distance from shore and differences in sediment trap accumulation rates and particle size characteristics. Depth was included in the analysis as depth is known to influence sediment dynamics (Wolanski et al., 2005) as well as declines in light associated with suspended sediments (Falkowski et al., 1990). A distance- based resemblance matrix was created for the biological data set using Bray-Curtis similarity values following a square-root transformation and for the environmental data using Euclidean distances and normalised values. A DISTLM, using the BEST fit model with the Akaike's Information Criterion (AIC) and 9,999 permutations was performed using the resemblance matrices. The multivariate scale relationship between the predictor (environmental) and response variables 258 (biological) was presented on a plot with a distance- based redundancy analysis (dbRDA; 
260 differences in health status among sites again a DISTLM model was used followed by dbRDA

261 plotting as above. Predictor variables included substrate structure (hard coral cover (HCC),

262 diversity) and physical conditions (depth, sediment trap accumulation rate, particle size

263 characteristics, distance from both river mouths and distance from shore). Hard coral cover

264 (HCC) and diversity were used since higher HCC can contribute to a greater probability of

265 impaired coral health (Bruno and Selig, 2007). In contrast, reefs that are more diverse can lower

266 susceptibility as it reduces the quick spread of a disease (Raymundo et al., 2005; Aeby et al.,

267 2011). As sediment data were obtained at the end of the wet season (May 2017), these were used

268 to explain the 2017 health data. For the 2016 coral health data, which had no associated sediment

269 data, only sampling year, HCC and coral diversity together with distance from shore and rivers

270 were used as explanatory variables.

271

272

\section{RESULTS}

\section{Physical parameters}

275 The dry season was characterized by less variable, warmer SST's (mean monthly range $=30.0$ to $27630.7^{\circ} \mathrm{C}$; sup Fig. 2), greater in-water light penetration (mean monthly range at $\mathrm{EG}=156$ to 320

$277 \mu$ mol photons $\mathrm{m}^{-2} \mathrm{~s}^{-1}$ ) and reduced rainfall (mean monthly rainfall range $=78$ to $166 \mathrm{~mm}$ ) and 278 cloud cover (Fig. 2). In contrast, the wet season was cooler (mean monthly range $=28$ to 30.1

$279{ }^{\circ} \mathrm{C}$ ) with higher rainfall (mean monthly range 126 to $234 \mathrm{~mm}$ ) and reduced light levels on the 280 reef (mean monthly range at $\mathrm{EG}=19$ to $150 \mu \mathrm{mol}$ photons $\mathrm{m}^{-2} \mathrm{~s}^{-1}$ ). Wind speeds were also 281 slightly elevated during the wet season months (Fig. 2d). Mean sediment trap accumulation rates 282 following the wet season ranged from 13 to $28 \mathrm{mg} \mathrm{cm}^{-2}$ day $^{-1}$, with a rate almost three times 283 higher at $\mathrm{EG}$ compared to $\mathrm{AG}$ and $\mathrm{SW}\left(\mathrm{H}_{2}=10.3\right.$, $\mathrm{p}<0.005$; Fig. 3). Site differences in potential 284 sediment load were also observed during the dry season with higher and more variable turbidity 285 recorded at the nearshore EG reef (mean monthly range $=<1$ to 24 FTU) than at SW (mean monthly range $=1-7$ FTU) located $10 \mathrm{~km}$ further south from the large Baram river mouth (sup 287 Fig. 3).

All three reefs were dominated by sand $(>98 \%)$, with the median particle size of benthic 290 sediments significantly increasing $\left(\mathrm{F}_{2}=13.6, \mathrm{p}<0.005\right)$ with distance from the mouths of the 291 Baram and Miri rivers (Fig. 4). Benthic sediments at SW comprised 58\% of very coarse sand, 
292 nearly three times that of EG (20\%) $\left(\mathrm{F}_{3}=24.9\right.$, p<0.001; PH: SW>EG,AG; sup Fig. 4) and a 293 significantly smaller proportion of medium/fine sands $\left(\mathrm{F}_{2}=17.2, \mathrm{p}=<0.001 ; \mathrm{PH}: \mathrm{SW}>\mathrm{AG}>\mathrm{EG}\right)$. 294 In contrast there was little difference in the median particle size from the sediment traps among 295 sites $\left(\mathrm{F}_{2}=2.25, \mathrm{p}=0.133\right)$, although particle sizes of the benthic sediment were significantly 296 greater compared to the trapped sediments $\left(\mathrm{F}_{1}=60.93, \mathrm{p}<0.001\right)$.

297

298

299

\section{Benthic cover}

Hard coral cover increased with distance from the major sediment source (Baram River) and 300 varied significantly among sites $\left(\mathrm{F}_{2}=5.3, \mathrm{p}=0.01\right.$; $\mathrm{PH}$ : $\left.\mathrm{SW}>\mathrm{EG}\right)$. SW had the highest HCC

301 (39.3\%) and EG almost half the HCC (21.9\%; Fig. 5). Soft corals also varied significantly but

302 declined with increasing distance from the major sediment source $\left(\mathrm{H}_{2}=8.6, \mathrm{p}=0.01\right.$; MWPH:

303 EG $>A G, S W$ ) with EG having nearly 15 -fold higher cover than SW. Turf algae dominated the 304 algal community and contributed to $52-57 \%$ of all reefs' benthos. However, there was no 305 significant difference in turf algal cover among reefs $(F 2=0.103, p>0.05)$. Recently dead coral 306 cover was consistently low among sites (4.25\%) as was crustose coralline algae, which was typically covered in turf algae.

308

309

In total 28 genera were recorded (Table 1). Coral diversity was considerably different among sites $\left(\mathrm{F}_{2}=4.6, \mathrm{p}=0.03\right.$; $\mathrm{PH}$ : $\left.\mathrm{SW}>\mathrm{EG}\right)$ with $\mathrm{SW}$ having the highest richness and 25 genera $\left(H^{\prime}=1.93\right)$, and EG and AG 16 and 14 genera, respectively $\left(H^{\prime} \sim 1.4\right)$. The surveyed sites were composed of similar communities, with the most dominant genera including Diploastrea sp., Porites sp., Montipora sp., Favites sp., Dipsastrea sp. and Pachyseris sp. (Table 1). All other species comprised a small fraction of the community ( $<2 \%$ cover). Most notable differences in the composition were with the high cover of Diploastrea sp. at AG and EG, Galaxea sp. at EG, and Acropora and Montipora sp. at SW.

Coral reef health

319 Of the compromised health signs recorded at each reef, the five most commonly observed were 320 mucus production $(0.5 \pm 0.3 \%)$, pigmentation response $(2.2 \pm 0.7 \%)$, bioerosion $(6.6 \pm 2 \%)$, bleaching $(6.7 \pm 0.9 \%)$ and scars $(1.1 \pm 0.4 \%$; Fig. 6$)$. No diseases per se were observed except at EG where one colony of massive Porites sp. had ulcerative white spots. Despite a decline in 
323 the prevalence of compromised health along an inshore to offshore gradient following the dry 324 season in 2016, total prevalence (sum of the five commonly observed signs) was not statistically 325 significant among sites and seasons ( $\mathrm{p}>0.05$; Table 2$)$. The prevalence of mucus production by 326 corals at Eves Garden (5\%), however, was nearly five times that of other reefs $\left(F_{2}=3.6 ; p<0.05\right.$; $327 \mathrm{EG}<\mathrm{AG}, \mathrm{SW}$ ), and $\mathrm{SW}$ recorded the lowest levels of pigmentation prevalence (Table 2; $\mathrm{F}_{2}=5.3$; $328 \mathrm{p}<0.05 ; \mathrm{AG}>\mathrm{SW})$. In contrast, bioerosion was comparatively similar among sites within each 329 season, but increased five-fold from $2.7 \pm 0.6 \%$ to $10 \pm 1.3 \%$ following the 2017 wet season 330 (Table 1; F=20.2; $\mathrm{p}<0.001 ; 2017>2016$; Fig 7). During both seasons, overall bleaching 331 prevalence was $\leq 10 \%$ with partially bleached the most common form and whole bleaching the 332 least observed (sup Fig. 5). Bleaching prevalence declined from $8.1 \pm 1.4 \%$ following the dry season to $5.4 \pm 1.1 \%$ after the wet season. Although this decline was not statistically significant $334(\mathrm{~F}=3.3 ; \mathrm{p}=0.08)$, the recovery of bleached corals that had been tagged the year before was 335 significant $(\mathrm{p}=0.002)$. The average bleaching scale dropped from $3.9 \pm 0.4$ to $1.6 \pm 0.2$ (Fig. 8 ) with all Diploastrea sp. and Pachyseris sp. colonies recovered by $90-100 \%$ in 2017.

Patterns of compromised health differed among five representative coral genera (Acropora sp., Montipora sp., Pachyseris sp., Diploastrea sp. and Porites sp.). Acropora sp. displayed the least signs of stress in both seasons $(<3.5 \%)$. Porites sp. were the most compromised $(2016=50.8 \pm$ $6 \% ; 2017=72 \pm 5 \%$; Fig. 9) and the only coral genera with a significant increase in stress symptoms ( $p=0.004)$, because of a $40 \%$ increase in bioerosion after the wet season $\left(F_{1}=10.17\right.$; $\mathrm{p}<0.001$; Table 3). Montipora sp. and Diploastrea sp. also suffered from an increase in bioerosion between sampling seasons, although this was not statistically significant ( $p>0.05$; Table 3). Despite a slight increase in the number of bleached Porites sp. corals, bleaching occurrence for the other four corals declined, most notably for Pachyseris sp. (55\% to 3\%;

$\left.347 \quad \mathrm{~F}_{1}=9.03 ; \mathrm{p}=0.008\right)$. Furthermore, the most abundant genus Porites sp. was the only coral to 348 show elevated signs of pigmentation $(>10 \%)$ although this health sign was less prevalent at SW, 349 the most offshore site $(\mathrm{F} 2=5.3 ; \mathrm{p}=0.01$; Table 3$)$.

350

For the three coral genera, Montipora sp., Pachyseris sp. and Acropora sp., there was no significant difference in symbiont density $(\mathrm{H}=4.0397, \mathrm{df}=2, \mathrm{p}>0.05)$ and chlorophyll $a$ among sites $(H=2.3769, p>0.05)$ although $\mathrm{SW}$ scored the highest of both measures $\left(3.2^{*} 10^{6} \pm 5.5\right.$ 
354 cells $/ \mathrm{cm}^{2} ; 4.94 \pm 0.75 \mu$ g.cm ${ }^{2} ;$ Fig. 10$)$. Symbiont density differed among the three coral genera 355 (chi-square $=23.1, \mathrm{df}=2, \mathrm{p}<0.001$; MWPH: AC $>\mathrm{MT}, \mathrm{PH}$ ) with Acropora sp. scoring four and 356 five times higher symbiont densities (sup Fig. 6). Over 50\% of the symbionts observed where 357 healthy (stage 1; sup Fig. 7a) with slightly more healthy cells observed at SW $(\mathrm{H}=1.7, \mathrm{p}>0.05)$ 358 and marginally more degraded cells (stage 5) observed at $\mathrm{AG}(\mathrm{H}=3.4, \mathrm{p}>0.05)$. Among genera, 359 Acropora had a greater number of healthy cells $(69 \pm 3.9 \%)$ than both Montipora $(49.4+5)$ and 360 Pachyseris $(52.6 \pm 4.8 ; \mathrm{H}=14.4, \mathrm{p}<0.001 ;$ sup Fig. $7 \mathrm{~b})$.

361

362

363

364

365

366

367

368

369

370

371

372

373

374

375

376

377

378

379

380

381

382

383

384

\section{Environmental associations with benthic cover and health}

Environmental variables (depth, sediment trap accumulation rate, distances from shore/river mouth, concentration of silt/fine/coarse particles, median particle size) explained $62.5 \%$ of the variation in benthic composition among reefs. Key drivers $(p<0.05)$ were distance from river mouth (30.3\%) and shore (1\%), median particle size (16.4\%), and sediment trap accumulation rate $(2.3 \%$; Table 4$)$. Variability among sites was higher than within, with sediment trap accumulation rate and particle size a key driver of benthos at EG and AG, and distance of river and shore more closely associated with SW (Fig. 11).

To determine key drivers of coral health, two DistLM models were run. The first model included health data from both sampling seasons, with six explanatory variables (season, HCC, diversity, distance from river mouth and shore, and depth). The second model included health data and sediment related variables following the wet season and sediment trap contents (sediment trap accumulation rate, concentration of silt/fine/course sediments, median particle size). For the first model, year, HCC and diversity significantly explained $<31 \%$ of the variation in coral health among transects and sites (Table 5). Sites within a sampling season were separated along a HCC and diversity gradient (Fig. 12), with transects at SW typically characterised by higher HCC and diversity but lower prevalence of scars, pigmentation and bleaching (sup Fig. 8). Furthermore, repeat transects were separated between seasons, with those completed in 2017 recording higher bioerosion, but lower bleaching and pigmentation (sup Fig. 7), supporting our previous results. Of the sediment drivers, the BEST model included both silt and the course sediments, which explained $18 \%$ of the variations in coral health in 2017 . Higher sediment trap accumulation rates, although not statistically significant ( $\mathrm{p}=0.06$; Table 5), 
385 explained $7 \%$ of the variation in health, and were most often associated with higher prevalence 386 of pigmentation, bioerosion and bleaching (sup Fig. 9).

387

388

389

390

391

392

\section{DISCUSSION}

The three reef sites in the MSCRNP are characterised by healthy coral cover yet low coral diversity. Average live coral cover among the three reefs was 30\%, ranging from $22 \%$ at $\mathrm{EG}$ to $39 \%$ at Siwa Reef. This is lower than reefs to the north in Sabah, with reports of live coral cover from 23 to 75\% (Pilcher and Cabanban, 2000; Chou and Tun, 2002; Lee, 2007; Praveena et al.,

393

394

395

396

397

398

399

400

401

402

403

404

405

406

407

408

409

410

411

412

413

414 2012; Waheed et al., 2016), but greater than the average coral cover for the wider Pacific region, estimated at 22\% in 2003 (Bruno and Selig, 2007). Previous assessment of coral cover in the early 2000s on the Miri reefs range from 28\% (Pilcher and Cabanban, 2000) to 22-58\% (Elcee Instumentation, 2002). Although the higher coral cover reported by the latter study is most likely an artefact of the methodology used (ex-situ Acoustic Ground Discrimination System), which can result in the misidentification and, therefore, quantification of live coral cover. Regardless, our data suggest that coral cover at Miri's reefs has been relatively stable over the last two decades. Miri's coral cover is comparable to both turbid and clear water reefs (Roy and Smith, 1971; Loya, 1976; Larcombe et al., 2001; Wesseling et al., 2001; Palmer et al., 2010; Goodkin et al., 2011), yet diversity was comparatively low (14 to 25 genera per reef) for the Coral Triangle region. Turak and Devantier (2010) reported 391 coral species ( 70 genera) on reefs near Brunei ( $\sim 80 \mathrm{~km}$ from Miri), and Teh and Cabanban (2007) reported 120 species within 71 hard coral genera for Banggi Island in Sabah. A comprehensive biodiversity assessment of all 30 reefs with the MSCRNP in 2001 reported 66 genera (203 coral species; Elcee Instumentation, 2002). We only observed a third of the number of coral genera $(n=28)$, which is expected given we surveyed only $10 \%(\mathrm{n}=3)$ of the reefs surveyed in 2001 . However, this report also found that coral diversity was highly variable among reefs, with an average of nine coral genera per transect. It is likely that MSCRNP reefs found further to the south and in deeper (15-35 m) offshore waters but outside the scope of this study (characterized by different environmental conditions) include several coral species not observed at our shallow nearshore sites, which are influenced by terrestrial sedimentation from both natural and anthropogenic processes. 
415 Low diversity at the surveyed sites is likely the result of poor water quality in the nearshore 416 shallow coastal zone. The inshore reefs of Miri are found in a narrow depth range between 7 to $41715 \mathrm{~m}$, hence there is a complete lack of reef structure at 1-5 m. These very shallow depths, 418 however, are often characterised by a distinct set of coral species (Morgan et al., 2016; 419 DeVantier and Turak, 2017). Given that lack of reef structure at these shallow depths in Miri, 420 this in part may explain lower coral diversity than on reefs to the north in Brunei and Sabah that 421 have reached sea level. But these inshore reefs are also characterised by high levels of 422 terrigenous sediments, which can also reduce coral diversity (Rogers, 1990; Fabricius, 2005).

423 High sediment input from rivers are typically correlated with high nutrient loads that can lead to 424 increase in reef algal biomass (De'ath et al., 2012). Algal cover on all three reefs was high $425(>50 \%)$ compared to reefs in northern Borneo (0 to 29\%; Waheed et al., 2015), and will most 426 likely be competing with corals for reef space. Some coral taxa will be less resilient to both 427 sediments and algal competition resulting in lower coral diversity (Fabricius et al., 2005; De'ath 428 and Fabricius, 2010). In Indonesia, Edinger et al. (1998), recorded lowest coral diversity on 429 reefs with algae cover reaching $46 \%$. Reduced diversity was also attributed to land pollution as 430 well as destructive and over-fishing practices that destroy the reef structure and reduce fish 431 biomass thereby removing the top-down control on algal growth by herbivore browsers (Hughes, 432 1994; Rogers and Miller, 2006; De'ath and Fabricius, 2010). In Miri, overfishing and poor land 433 management practices have been a long-term concern for the regional government (Elcee 434 Instumentation, 2002) but there are limited funds to actively protect the reefs (Teh and Teh, 435 2014) and collect data on these impacts.

436

437 Low coral diversity does not necessarily suggest a degraded reef condition. Typically, low 438 diversity in nature results in lower resilience (Raymundo et al., 2005) and community stability 439 (Bellwood et al., 2004). Yet there is growing evidence to suggest that a few but tolerant species 440 can maintain reef resilience to local and global impacts, and implies that the diversity-resilience 441 links need further investigation (Bellwood et al., 2004; Fabricius et al., 2005; Nystrom et al., 442 2008). A recent study on relatively undisturbed and well protected reefs in the Philippines that 443 looked to identify site specific benchmarks for coral diversity, measured high coral cover $(>30 \%)$ 444 at the majority of sites, but low generic diversity (10 to 25 coral genera per $75 \mathrm{~m}$ by $25 \mathrm{~m}$ area; 445 Licuanan et al., 2017). This highlights that high diversity is not necessarily a key benchmark for 
446 a healthy reef system. As well as assessing diversity on a reef, it is important to determine if and 447 how coral community structure has changed over time. Significant shifts in coral composition 448 can affect the reef's ecological function such as framework building, habitat complexity and food 449 source diversity (Aronson et al., 2004; Pratchett, 2005; Graham et al., 2006). At six reef sites on 450 the Great Barrier Reef coral communities shifted over 12 years towards a high abundance of 451 Porites spp. and soft corals; a community assemblage that is less likely to re-establish to the pre452 disturbance coral assemblage (Johns et al., 2014). Inshore reefs in Miri are similarly dominated 453 by massive corals including Porites sp. and Diploastrea sp., with some (e.g. EG) also

454 characterized by high soft coral cover $(>10 \%)$. While we have no long-term data sets to evaluate 455 change in both diversity and composition, Miri’s reefs may have experienced a community shift 456 due to reduction in water quality. Yet our tendency as coral reef ecologists to focus on coral 457 cover, composition and diversity, has resulted in a misconception as to what constitutes an 458 overall healthy reef (Vroom, 2011). Some reefs may naturally be dominated by non-coral 459 organisms, such as calcifying algae that are equally important for reef accretion and stability, but 460 possibly less resilient to climate change. Thus our perception of the reefs current state and its 461 future trajectory are likely inaccurate and need adjusting to go beyond diversity assessments. 462

463 The MSCRNP reef community can best be described as representative of turbid reefs in the 464 Indo-Pacific. The dominant coral species include several genera (Acropora, Montipora, Porites, 465 Pachyseris, Favites and Galaxea spp.) that have been observed on nearshore reefs in Singapore 466 (Chou, 1988; Dikou and van Woesik, 2006), the Great Barrier Reef (GBR) (Ayling and Ayling, 467 1991; Larcombe et al., 2001; Browne et al., 2010; Morgan et al., 2016), Thailand (Tudhope and 468 Scoffin, 1994), Hong Kong (Goodkin et al., 2011) and Sabah (Pilcher and Cabanban, 2000). 469 These corals are considered to be more resilient to sediment influx either through: 1) enhanced 470 photo-acclamatory abilities required during periods of low light (e.g. Stylophora; Dubinsky et al., 471 1984; Browne et al., 2014), 2) active sediment removal processes by the coral polyp (e.g.

472 Goniastrea; Rogers, 1990; Erftemeijer et al., 2012), 3) enhanced mucus production to remove 473 settled sediments (e.g. Porites; Bessell-Browne et al., 2017) or, 4) morphological advantages that 474 result in greater degree of vertical growth thereby reducing tissue mortality from sediment burial 475 (e.g. Acropora and Montipora; Erftemeijer et al., 2012). There were also distinct differences in 476 the community assemblages particularly between Siwa Reef and Eve's Garden. Siwa Reef had a 
477 mixed assemblage of branching, foliose and massive corals, whereas Eve's Garden was

478 dominated by massive corals, such as Porites sp. and Diploastrea sp. These coral community

479 differences suggest there are significant differences in environmental drivers (including

480 sediments) over a comparatively small spatial scale (10 km’s).

481

482 The inshore to offshore gradient in hard coral cover and diversity, and differences in coral

483 composition is heavily influenced by the spatial differences in sediment related parameters. Over

$48462 \%$ of the variation in benthic cover at our three reef sites is explained by differences in depth,

485 sediment trap accumulation rates and distance from sediment sources as well as sediment particle

486 size characteristics. Consequently, we saw a significant increase in both coral cover and diversity

487 with increasing distance from the river mouths. Similar observations have been reported from

488 Indonesia and Puerto Rico, where hard coral cover nearly halved towards shore (Loya, 1976;

489 Edinger et al., 2000), and in Hong Kong, where inshore coral cover was 20\% lower than offshore

490 (Goodkin et al., 2011). Reduced coral cover occurs because of low larval recruitment as a

491 consequence of limited hard substrate following sediment settling (Birrell et al., 2005; Fabricius,

492 2005; Dikou and van Woesik, 2006), colony mortality caused by anoxic conditions that occur

493 under sediment layers (Rogers, 1983; Riegl and Branch, 1995; Wesseling et al., 2001), or lower

494 coral growth as a result of limited light or more energy used for sediment clearing (Browne,

495 2012). The sediment particle size and source (marine versus terrestrial) are considered equally

496 important to sediment volume in assessing the impacts of sediments on coral health (Weber et

497 al., 2006). A recent study demonstrated that as the percentage of terrestrial sediments increases,

498 there are greater declines in coral cover (Bégin et al., 2016). The significantly lower hard coral

499 cover and diversity at EG than at SW could be driven in part by a higher volume of terrestrial

500 sediments from the Baram and Miri rivers. Although we did not assess sediment origin,

501 sediment trap accumulation rates at EG were over double that at AG and SW, which may be due

502 to the reefs closer proximity to the two river mouths. However, it could also be the result of

503 increased sediment resuspension in shallow water or a combination of these factors. Sediment

504 traps do not provide a comprehensive assessment of sediment dynamics on reefs, and given that

505 our traps were out for 7 months, we recognize that our monthly sediment trap accumulation rates

506 can only be compared among our study sites and not to other studies. Regardless, it is likely that

507 river flow and sediments are influencing reef health, but these reefs appear to be in a temporally

Peer) reviewing PDF | (2018:10:31951:2:0:ACCEPTED 24 Jun 2019) 
508 stable state given low recently dead coral cover $(4.35 \%)$ and the limited decline in coral cover

509 over the last two decades.

510

511 The prevalence of impaired health signs was dominated by bioerosion and pigmentation response

512 with no signs of coral disease (with one exception). These health indicators are typically related

513 to high sediment and nutrient influx. High levels of bioerosion in particular has been linked to

514 land based pollution whereby lower light, from high turbidity, reduces $\mathrm{CaCO}_{3}$ density (Risk and

515 Sammarco, 1991; Lough and Barnes, 1992) weakening the coral skeleton and increasing

516 susceptibility to bioeroders (e.g. molluscs, worms etc.; Prouty et al., 2017). Furthermore, even

517 modest increases in nutrient levels can lead to an increase in the abundance of bioeroding

518 organisms shifting a reef community from one of net production to net erosion (Hallock and

519 Schlager, 1986; Hallock, 1988; Prouty et al., 2017). Bioerosion levels were significantly greater

520 following the wet season when the impact of sediments on the Miri reefs were elevated as

521 indicated by declines in light and higher suspended sediment loads. Conversely, pigmentation

522 rates were higher following the dry season. Pigmentation is an indicator of immune function in

523 response to a stressor (Willis et al., 2004; Palmer et al., 2009). These stressors have been related

524 to settling sediments (Pollock et al., 2014) or lesions from abrasion or scars (Willis et al., 2004),

525 or for the case of Miri reefs elevated SST's recorded in the region in 2016 leading to the

526 moderate bleaching event as observed by the diving operators and fisherman. Spatially,

527 pigmentation rates were significantly lower at Siwa, which may suggest that corals at the least

528 sediment impacted site were also less stressed than at AG and EG. Sediments can also promote 529 diseases in corals (Voss and Richardson, 2006; Haapkyla et al., 2011; Pollock et al., 2014) with

530 Black Band Disease and White Plague widely observed in the Indo-Pacific (Harvell et al., 2007;

531 Beeden et al., 2008), although generally low ( $\sim \%$ of current global records) in SE Asian reefs

532 compared to the Caribbean (Green and Bruckner, 2000). Suggested explanations for this include

533 poor reporting of coral diseases and relatively high coral diversity that might aid in diminishing a

534 quick spread of a disease (Raymundo et al., 2005). At Miri, the more likely explanation of low to

535 no coral diseases are more resilient individual corals and coral species, and potentially limited

536 connectivity with nearby coral populations, although this remains speculative until further work

537 is carried out.

538 
539 Hard coral cover and diversity also explained a significant portion of the variation in coral

540 health. Miri reefs with a higher frequency of impaired health at sites recorded less coral cover

541 and diversity. In a recent study by Miller et al., (2015) reefs in Sabah had four common coral

542 diseases at varying frequencies $\left(<0.1\right.$ to 0.6 per affected colonies in an $\left.\mathrm{m}^{2}\right)$ and signs of tissue

543 necrosis and pigmentation responses. They found a positive correlation between disease

544 frequency and coral cover, which suggested that host density was a key driver of disease

545 prevalence and compromised health. This relationship is due to reduced distances between

546 colonies, and greater shading and competition by fast growing species as coral cover increases

547 (Bruno and Selig, 2007). In Miri, we see the reverse trend suggesting that factors other than host

548 density are driving coral health, potentially changing sediment loads and finer sediment particles

549 not present in Sabah. However other variables often associated with sediment such as nutrient

550 levels and pollution such as heavy metal loads are also worth investigating.

551

552 Variable species composition among sites would also partly explain the spatial variation in coral

553 health. Different coral taxa have different susceptibilities to bioerosion, bleaching, disease and

554 compromised health (Raymundo et al., 2005; Couch et al., 2014; Heintz et al., 2015). In Miri

555 signs of pigmentation and bioerosion were most prominent on massive Porites sp. colonies.

556 Porites sp., although typically considered a hardier coral taxa (Raymundo et al., 2005) tolerant of

557 turbid waters, often have the most lesions, highest tissue loss and pigmentation response

558 (Tribollet et al., 2011; Pollock et al., 2014; Heintz et al., 2015) as well as being a target for

559 disease (Raymundo et al., 2005). The level of bleaching observed in Porites at Miri was

560 comparable to other abundant coral genera, but recovery potential after 9 months was lower,

561 possibly due to other stress symptoms. Bleaching was the most common sign of impaired health

562 among coral taxa, most commonly observed in Pachyseris, Porites, Montipora, Dipsastrea and

563 Acropora spp. (in declining order). A comprehensive study by Marshall and Baird (2000) of 40

564 coral taxa on the GBR found the same coral taxa were highly ( $>50 \%$ bleached or dead) or

565 severely ( $>15 \%$ dead) susceptible to thermal stress. In contrast, the other five most abundant

566 corals at Miri (Diploastrea, Favites, Galaxea, Echinopora, Merulina spp.) are considered to be

567 less sensitive to rising SST's (Marshall and Baird, 2000; Guest et al., 2016). However, bleaching

568 susceptibility does vary considerably according to the thermal history of a region. For example,

569 Acropora sp. is susceptible to bleaching on some reefs (Marshall and Baird, 2000; Pratchett et 
570 al., 2013; Hoogenboom et al., 2017), but was less susceptible on other reefs (e.g. Singapore 571 following the 2010 bleaching event: Guest et al., 2012). Only 5\% of Acropora sp. colonies in 572 Miri showed signs of thermal stress, which suggests moderate thermal tolerance to high SST's.

573 High levels of algal density in coral tissue are also linked to higher thermal stress resistance 574 (Glynn, 1993; Stimson et al., 2002) due to the symbionts providing a greater concentration of 575 mycosporine-like amino acids that protect corals from UV radiation (Xu et al., 2017). Symbiont 576 densities measured at Miri were high (mean $=2.4 * 10^{6}$ cells per $\mathrm{cm}^{2}$ ) but comparable to corals 577 on other turbid reefs like those from Singapore (e.g. 0.5 to $3^{*} 10^{6}$ cells per $\mathrm{cm}^{2}$ (Browne et al., 578 2015). However, it was Acropora sp. that had significantly higher symbiont density than the 579 more frequently bleached Montipora sp. and Pachyseris sp. Our results suggest that resilience to 580 stress for these corals is a complex, but synergistic relationship between the level and frequency 581 582

583 584 585 of environmental stressors, community composition and a coral's adaptability to increased SST.

587

588

589

590

591

592

593 594

595

596

597

598

599

600

In 2016, a severe coral bleaching event occurred throughout the Indo-Pacific region. The impacts of this event were thoroughly assessed on the GBR, where over $90 \%$ of reefs bleached resulting in the loss of $29 \%$ of shallow water coral cover (Great Barrier Reef Marine Park Authority, 2016). In January to March 2016, SST along the northern shore of Borneo were in the highest 10\% of global records since 1990 (Great Barrier Reef Marine Park Authority, 2016). SST reported by NOAA for Brunei peaked in May to June 2016 at $31^{\circ} \mathrm{C}$ (the bleaching threshold temperature; Fig. 12). During this time there was 1 to 2.5 Degree Heating Weeks (DHW) and mid-level bleaching warnings. SST remained at $\sim 30^{\circ} \mathrm{C}$ until January 2017 (National Oceanic \& Atmospheric Administration, 2018), which agree with our in-water assessment of SST during September 2016 to early 2017 (sup Fig. 2). This suggests that while corals at Miri were subject to elevated SST's for 5 or more months, our surveys revealed comparatively low bleaching rates ( $\sim 10 \%$ of colonies bleached), and high recovery rates (as suggested by the tagged corals; $>90 \%$ ). This suggests that these nearshore turbid water reefs are resilient to high SST's supporting the growing body of evidence that turbid reefs bleach less severely and frequently than their clearwater counterparts (Marshall and Baird, 2000; Heintz et al., 2015; Morgan et al., 2017). Low bleaching and high recovery rates of Miri reefs is possibly due to nearshore coral assemblages more frequent exposure to higher temperatures than their offshore deeper conspecifics, resulting in the development of adaptive mechanisms (Marshall and Baird, 2000; Guinotte et al., 2003; 
601 Guest et al., 2016; Morgan et al., 2017). It may also be due to lower UV light penetration that 602 can exacerbate temperature stress (Courtial et al., 2017), or potentially from higher heterotrophy, 603 which increases the supply of essential metals to the symbionts thus sustaining them through 604 elevated temperatures (Ferrier-Pagès et al., 2018). This study further suggests that while turbid 605 reefs are potentially more resilient to elevated SST, the mechanism/s responsible for this 606 resilience remain unclear.

607

608 CONCLUSIONS

609 In conclusion, the MSCRNP reefs are characterized by relatively high coral cover, low

610 prevalence of impaired health and are composed of a few but tolerant coral taxa. Low recently

611 dead coral cover and potentially limited decline in coral cover over the last two decades indicates

612 these reefs are stable despite elevated sediment inputs and regular exposure to thermal stress

613 events. There are, however, potential risks from proposed coastal and in-land developments

614 given we found that sediment related parameters have resulted in an on- to offshore gradient in

615 coral cover, diversity and health. Furthermore, high bioerosion and algae cover indirectly

616 suggests high nutrient influx, most likely from the Baram River. The high prevalence of

617 bioerosion observed in Porites sp. colonies is a concern given that this coral is a key reef

618 framework builder, and any notable declines in Porites sp. health will reduce coral reef

619 complexity and habitat availability for other invertebrate and fish species. Currently, there is no

620 baseline data on spatial and temporal changes in river outputs and sediment plume dynamics

621 within the MSCRNP, which is crucial in evaluating future threats to these reefs. Local

622 management agencies will need to address this knowledge gap if they plan to develop strategies

623 that address the potential impacts of changing land use on MSCRNP. The reefs current health

624 state and elevated stress tolerance does, however give hope that these reefs could be resilient to

625 future climate change but only if local water quality does not deteriorate.

626

627

\section{ACKNOWLEDGEMENTS}

629 We would like to thank the Curtin Sarawak Research Institute for facilitating this research, 630 especially Prof Clem Kuek and Ms Daisy Saban who worked tirelessly to make sure our research 631 trips went to plan. We thank our volunteers Amitay Moody, Hedwig Krawczyk (who also 632 produced Figures 1 and 12), Paula Cartwright, Toloy Keripin Munsang, Valentino Anak Jempo, 
633 Sun Veer and the numerous volunteers from the Curtin Sarawak Dive Club for their assistance

634

635

636

637

638

639

640

641

642

643

644

645

646

647

648

649

650

651

652

653

654

655

656

657

658

659

660

661

662

663

664

665

666

667

668

669

670

671

672

673

674

675

676

677

678

with field work. Thanks also to the captains and crew from Coco Dive Centre and Hoopa Dive.

\section{REFERENCES}

Aeby, G., Bourne, D., Wilson, B., Work, T. M., 2011. Coral diversity and the severity of disease outbreaks: A cross-regional comparison of Acropora White Syndrome in a species-rich region (American Samoa) with a species-poor region (Northwestern Hawaiian Islands). Journal of Marine Biology, 2011.

Aronson, R. B., MacIntyre, I. G., Wapkin, C. M., O'Neil, M. W., 2004. Phase shifts, alternative states and the unprecedented convergence of two reef systems. Ecology, 85, 1876-1891.

Ayling, A. M., Ayling, A. L. (1991). The effect of sediment run-off on the coral populations of the fringing reefs at Cape Tribulation. Research publication No. 26, Great Barrier Reef Marine park Authority

Bainbridge, Z. T., Wolanski, E., Álvarez-Romero, J. G., Lewis, S. E., Brodie, J. E., 2012. Fine sediment and nutrient dynamics related to particle size and floc formation in a Burdekin River flood plume, Australia. Marine Pollution Bulletin, 65(4-9), 236-248.

Beeden, R., Willis, B. L., Raymundo, L. J., Page, C. A., Weil, E., 2008. Underwater cards for assessing coral health on Indo-Pacific reefs. Coral Reef Targeted Research and Capacity Building for Management Program. Currie Communications, Melbourne, 22.

Bégin, C., Schelten, C. K., Nugues, M. M., Hawkins, J., Roberts, C., Côté, I. M., 2016. Effects of protection and sediment stress on coral reefs in Saint Lucia. PLOS ONE, 11(2), e0146855. doi:10.1371/journal.pone.0146855

Bégin, C., Wurzbacher, J., Côté, I. M., 2013. Variation in benthic communities of eastern Caribbean coral reefs in relation to surface sediment composition. Marine Biology, 160(2), 343-353. doi:10.1007/s00227-012-2092-5

Bellwood, D. R., Hughes, T. P., Folke, C., Nystrom, M., 2004. Confronting the coral reef crisis. Nature, 429(6994), 827-833.

Ben-Haim, Y., Zicherman-Keren, M., Rosenberg, E., 2003. Temperature-regulated bleaching and lysis of the coral Pocillopora damicornis by the novel pathogen Vibrio coralliilyticus. Applied and Environmental Microbiology, 69(7), 4236-4242.

Bessell-Browne, P., Fisher, R., Duckworth, A., Jones, R., 2017. Mucous sheet production in Porites: an effective bioindicator of sediment related pressures. Ecological Indicators, 77, 276-285.

Birrell, C. L., McCook, L., Willis, B. L., 2005. Effects of algal turfs and sediment on coral settlement. Marine Pollution Bulletin, 51, 408-414.

Browne, N.K., (2012) Spatial and temporal variations in coral growth on an inshore turbid reef subjected to multiple disturbance events. Marine Environmental Research, 77, 71-83

Browne, N. K., Precht, E., Last, K. S., Todd, P. A., 2014. Photo-physiological costs associated with acute sediment stress events in three near-shore turbid water corals. Marine Ecology Progress Series, 502, 129-143. doi:10.3354/meps10714

Browne, N. K., Smithers, S. G., Perry, C. T., 2010. Geomorphology and community structure of Middle Reef, central Great Barrier Reef, Australia: an inner-shelf turbid zone reef

Peer) reviewing PDF | (2018:10:31951:2:0:ACCEPTED 24 Jun 2019) 
679

680

681

682

683

684

685

686

687

688

689

690

691

692

693

694

695

696

697

698

699

700

701

702

703

704

705

706

707

708

709

710

711

712

713

714

715

716

717

718

719

720

721

722

723

subjected to episodic mortality events. Coral Reefs, 29, 683-689. doi:10.1007/s00338010-0640-3

Browne, N. K., Tay, J. K. L., Low, J., Larson, O., Todd, P. A., 2015. Fluctuations in coral health of four common inshore reef corals in response to seasonal and anthropogenic changes in water quality. Marine Environmental Research, 105(0), 39-52.

Bruno, J. F., Selig, E. R., 2007. Regional decline of coral cover in the Indo-Pacific: Timing, extent, and subregional comparisons. PLOS ONE, 2(8), e711.

Bryan, J. E., Shearman, P. L., Asner, G. P., Knapp, D. E., Aoro, G., Lokes, B., 2013. Extreme differences in forest degradation in Borneo: comparing practices in Sarawak, Sabah, and Brunei. PLOS ONE, 8(7), e69679.

Burke, L., Reytar, K., Spalding, M., Perry, A., 2011. Reefs at risk. World Resources Institute, Washington, DC.

Cacciapaglia, C., van Woesik, R., 2015. Coral refugia in a rapdily changing ocean. Global Change Biology, 21(3), 2272-2282.

Cacciapaglia, C., van Woesik, R., 2016. Climate-change refugia: shading reef corals by turbidity. Global Change Biology, 22(3), 1145-1154.

Chou, L. K. L., Tun, K., 2002. The status of coral reefs of Pulau Banggi and its vicinity, Sabah, based on surveys in June 2002. Technical report 2/02. Singapore: National University of Singapore.

Chou, L. M., 1988. Community structure of sediment stressed reefs in Singapore. Galaxea, 7, 101-111.

Couch, C. S., Garriques, J. D., Barnett, C., Preskitt, L., Cotton, S., Giddens, J., Walsh, W., 2014. Spatial and temporal patterns of coral health and disease along leeward Hawai'i Island. Coral Reefs, 33(3), 693-704.

Courtial, L., Roberty, S., Shick, J. M., Houlbrèque, F., Ferrier-Pagès, C., 2017. Interactive effects of ultraviolet radiation and thermal stress on two reef-building corals. Limnology and Oceanography, 62(3), 1000-1013.

Crabbe, J. C., Smith, D. J., 2005. Sediment impacts on growth rates of Acropora and Porites corals from fringing reefs of Sulawesi, Indonesia. Coral Reefs, 24, 437-441.

De'ath, G., Fabricius, K., 2010. Water quality as a regional driver of coral biodiversity and macroalgae on the Great Barrier Reef. Ecological Applications, 20(3), 840-850.

De'ath, G., Fabricius, K., Sweatman, H., Puotinen, M., 2012. The 27-year decline of coral cover on the Great Barrier Reef and its cause. PNAS, 109, 1-5.

DeVantier, L., Turak, E., 2017. Species richness and relative abundance of reef-building corals in the Indo-West Pacific. Diversity, 9(3), 25.

Dikou, A., van Woesik, R., 2006. Survival under chronic stress from sediment load: Spatial patterns of hard coral communities in the southern islands of Singapore. Marine Pollution Bulletin, 52(11), 1340-1354.

Dubinsky, Z., Falkowski, P. G., Porter, J. W., Muscatine, L., 1984. Absorption and utilization of radiant energy by light- and shade-adapted colonies of the hermatypic coral Stylophora pistillata. Proceedings of the Royal Society of London. Series B, Biological Sciences, 222(1227), 203-214.

Edinger, E., Limmon, G. V., Jompa, J., Widjatmoko, W., Heikoop, J. M., Risk, M. J., 2000. Normal coral growth rates on dying reefs: Are coral growth rates good indicators of reef health? Marine Pollution Bulletin, 40(5), 405-425. 
724

725

726

727

728

729

730

731

732

733

734

735

736

737

738

739

740

741

742

743

744

745

746

747

748

749

750

751

752

753

754

755

756

757

758

759

760

761

762

763

764

765

766

Edinger, E. N., Jompa, J., Limmon, G. V., Widjatmoko, W., Risk, M. J., 1998. Reef degradation and coral biodiversity in indonesia: Effects of land-based pollution, destructive fishing practices and changes over time. Marine Pollution Bulletin, 36(8), 617-630.

Elcee Instumentation Sdn Bhd. (2002). An integrated approach to a reef management program (ReefMap) for the Miri-Sibuti Reefs Sarawak. Final report.

Erftemeijer, P. L. A., Riegl, B., Hoeksema, B. W., Todd, P., 2012. Environmental impacts of dredging and other sediment disturbances on corals: A review. Marine Pollution Bulletin, 64(9), 1737-1765.

Fabricius, K. E., 2005. Effects of terrestrial run off on the ecology of corals and coral reefs: review and synthesis. Marine Pollution Bulletin, 50, 125-146.

Fabricius, K. E., De'ath, G., McCook, L., Turak, E., Williams, D., 2005. Changes in algal, coral and fish assemblages along water quality gradients on the inshore Great Barrier Reef. Marine Pollution Bulletin, 51, 384-398.

Falkowski, P. G., Jokiel, P. L., Kinzie, R. A. (1990). Irradiance and corals. In Z. Dubinsky (Ed.), Ecosystems of the World 25: Coral Reefs. (pp. 89-107). Amsterdam: Elsevier.

Ferner, D., 2013. Reef corals of Miri area reefs, Sarawak, Malaysia. . Sarawak Museum Journal, The whales, porpoises and dolphins known in Sarawak waters. (5), 288-296.

Ferrier-Pagès, C., Sauzéat, L., Balter, V., 2018. Coral bleaching is linked to the capacity of the animal host to supply essential metals to the symbionts. Global Change Biology, $0(0)$.

Fidelman, P., Evans, L., Fabinyi, M., Foale, S., Cinner, J., Rosen, F., 2012. Governing largescale marine commons: contextual challenges in the Coral Triangle. Marine Policy, 36(1), 42-53.

Glynn, P. W., 1993. Coral reef bleaching: ecological perspectives. Coral Reefs, 12, 1-17.

Goodkin, N. F., Switzer, A. D., McCorry, D., DeVantier, L., True, J. D., Hughen, K. A., Angeline, N., Yang, T. T., 2011. Coral communities of Hong Kong: long-lived corals in a marginal reef environment. Mar.Ecol. Prog. Ser., 426, 185-196.

Graham, N., Wilson, S., Jennings, S., Polunin, N. V. C., Bijoux, J. P., Robinson, J., 2006. Dynamic fragility of oceanic coral reef ecosytems. PNAS, 103(22), 8425-8429.

Great Barrier Reef Marine Park Authority. (2016). Interim report: 2016 coral bleaching event on the Great Barrier Reef. Retrieved from http://elibrary.gbrmpa.gov.au/jspui/handle/11017/3044.

Green, E. P., Bruckner, A. W., 2000. The significance of coral disease epizootiology for coral reef conservation. Biological Conservation, 96(3), 347-361.

Guest, J. R., Baird, A. H., Maynard, J. A., Muttaqin, E., Edwards, A. J., Campbell, S. J., Yewdale, K., Affendi, Y. A., Chou, L., 2012. Contrasting patterns of coral bleaching susceptibility in 2010 suggest an adaptive response to thermal stress. PLOS ONE.

Guest, J. R., Low, J., Tun, K., Wilson, B., Ng, C., Raingeard, D., Ulstrup, K. E., Tanzil, J. T. I., Todd, P. A., Toh, T. C., McDougald, D., Chou, L. M., Steinberg, P. D., 2016. Coral community response to bleaching on a highly disturbed reef. Scientific Reports, 6, 20717. doi:10.1038/srep20717

Guinotte, J. M., Buddemeier, R. W., Kleypas, J. A., 2003. Future coral reef habitat marginality: temporal and spatial effects of climate change in the Pacific basin. Coral Reefs, 22, 551558.

Peer) reviewing PDF | (2018:10:31951:2:0:ACCEPTED 24 Jun 2019) 
767

768

769

770

771

772

773

774

775

776

777

778

779

780

781

782

783

784

785

786

787

788

789

790

791

792

793

794

795

796

797

798

799

800

801

802

803

804

805

806

807

808

809

810

811

Haapkyla, J., Unsworth, R., Flavell, M., Bourne, D. G., Schaffelke, B., Willis, B. L., 2011. Seasonal rainfall and runoff promote coral disease on inshore reef. PLOS ONE, 6(2), e16893.

Hallock, P., 1988. The role of nutrient availability in bioerosion: Consequences to carbonate buildups. Palaeogeography, Palaeoclimatology, Palaeoecology, 63(1-3), 275-291.

Hallock, P., Schlager, W., 1986. Nutrient excess and the demise of coral reefs and carbonate platforms. PALAIOS, 1(4), 389-398.

Harvell, D., Jordan-Dahlgren, E., Merkel, S., Rosenberg, E., Raymundo, L., Smith, G., Weil, E., Willis, B. L., 2007. Coral disease, environmental drivers, and the balance between baterial and microbial associates. Oceanography, 20(1), 173-195.

Heery, E. C., Hoeksema, B. W., Browne, N. K., Reimer, J. D., Ang, P. O., Huang, D., Friess, D. A., Chou, L. M., Loke, L. H. L., Saksena-Taylor, P., Alsagoff, N., Yeemin, T., Sutthacheep, M., Vo, S. T., Bos, A. R., Gumanao, G. S., Syed Hussein, M. A., Waheed, Z., Lane, D. J. W., Johan, O., Kunzmann, A., Jompa, J., Suharsono, Taira, D., Bauman, A. G., Todd, P. A., 2018. Urban coral reefs: Degradation and resilience of hard coral assemblages in coastal cities of East and Southeast Asia. Marine Pollution Bulletin, 135, 654-681.

Heintz, T., Haapkylä, J., Gilbert, A., 2015. Coral health on reefs near mining sites in New Caledonia. Diseases of aquatic organisms, 115(2), 165-173.

Hennige, S. J., Smith, D. J., Walsh, S. J., McGinley, M. P., Warner, M. E., Suggetta, D. J., 2010. Acclimation and adaptation of scleractinian coral communities along environmental gradients within an Indonesian reef system. Journal of Experimental Marine Biology and Ecology, 391, 143-152.

Hoogenboom, M. O., Frank, G. E., Chase, T. J., Jurriaans, S., Alvarez-Noriega, M., Peterson, K., Critchell, K., Berry, K. L., Nicolet, K. J., Ramsby, B., 2017. Environmental drivers of variation in bleaching severity of Acropora species during an extreme thermal anomaly. Global Change Biology, 11, 2251-2265.

Hughes, T. P., 1994. Catastrophes phase shifts and large scale degradation of a Caribbean coral reefs. science, 265(5178), 1547-1551.

Johns, K. A., Osborne, K. O., Logan, M., 2014. Contrasting rates of coral recovery and reassembly in coral communities on the Great Barrier Reef. Coral Reefs, 33(3), 553-563.

Kamp-Nielsen, L., Vermaat, J., Wesseling, I., Borum, J., Geertz-Hansen, O., 2002. Sediment properties along gradients of siltation in South-east Asia. Estuarine, Coastal and Shelf Science, 54(1), 127-137.

Kelley, R., 2009. Indo Pacific coral finder. See www. byoguides. com.

Kleypas, J. A., 1996. Coral Reef Development under naturally turbid conditions: fringing reefs near Broad South, Australia. Coral Reefs, 15, 153-167.

Kleypas, J. A., McManus, J. W., Menez, L. A. B., 1999. Environmental limits to coral reef development: Where do we draw the line? American Zoology, 39, 146-159.

Kohler, K. E., Gill, S. M., 2006. Coral point count with excel extensions (CPCe): A Visual basic program for the determination of coral and substrate coverage using random point count methodology. Computers \& Geosciences, 32(9), 1259-1269.

Lambiase, J. J., bin Abdul Rahim, A. A., Peng, C. Y., 2002. Facies distribution and sedimentary processes on the modern Baram Delta: implications for the reservoir sandstones of NW Borneo. Marine and Petroleum Geology, 19(1), 69-78.

Peer) reviewing PDF | (2018:10:31951:2:0:ACCEPTED 24 Jun 2019) 
812 Larcombe, P., Costen, A., Woolfe, K. J., 2001. The hydrodynamic and sedimentary setting of

813 near shore coral reefs, central Great Barrier Reef shelf, Australia: Paluma Shoals, a

814 casestudy. Sedimentology, 48, 811-835.

815 Lee, W. T. (2007). Coral reefs and marine benthic habitat mapping using hydroacoustics

816 methods. University Malaysia Sabah, Masters Thesis, University Malaysia Sabah.

817 Legendre, P., Anderson, M. J., 1999. Distance-based redundancy analysis: testing multispecies

818 responses in multifactorial ecological experiments. Ecological monographs, 69(1), 1-24.

819 Licuanan, W. Y., Robles, R., Dygico, M., Songco, A., van Woesik, R., 2017. Coral benchmarks

820 in the center of biodiversity. Marine Pollution Bulletin, 114(2), 1135-1140.

821

822

823

824

825

826

827

828

829

830

831

832

833

834

835

836

Lough, J. M., Barnes, D. J., 1992. Comparisons of skeletal density in Porites from the central Great Barrier Reef. Journal of Experimental Marine Biology and Ecology, 155, 1-25.

Loya, Y., 1976. Effects of water turbidity and sedimentation on the community structure of Puerto Rican corals. Bulletin of Marine Science, 26, 450-466.

Marshall, P. A., Baird, A. H., 2000. Bleaching of corals on the Great Barrier Reef: differential susceptibilities among taxa. Coral Reefs, 19(2), 155-163.

McManus, J. W., 1997. Tropical marine fisheries and the future of coral reefs: a brief review with emphasis on Southeast Asia. Coral Reefs, 16(1), S121-S127.

Miller, J., Sweet, M. J., Wood, E., Bythell, J., 2015. Baseline coral disease surveys within three marine parks in Sabah, Borneo. PeerJ, 3, e1391.

Morgan, K. M., Perry, C. T., Johnson, J. A., Smithers, S. G., 2017. Nearshore turbid-zone corals exhibit high bleaching tolerance on the Great Barrier Reef following the 2016 ocean warming event. Frontiers in Marine Science, 4, 224

Morgan, K. M., Perry, C. T., Smithers, S. G., Johnson, J. A., Daniell, J. J., 2016. Evidence of extensive reef development and high coral cover in nearshore environments: implications for understanding coral adaptation in turbid settings. Scientific Reports 6, 29616.

837

838

839

840

841

842

843

844

845

846

847

848

849

850

851

852

853

854

855

856

Mydlarz, L. D., McGinty, E. S., Harvell, C. D., 2010. What are the physiological and immunological responses of coral to climate warming and disease? The Journal of Experimental Biology, 213(6), 934-945.

Nagarajan, R., Jonathan, M., Roy, P. D., Muthusankar, G., Lakshumanan, C., 2015. Decadal evolution of a spit in the Baram river mouth in eastern Malaysia. Continental Shelf Research, 105, 18-25.

National Oceanic \& Atmospheric Administration. (2018). High Resolution SST data provided by the NOAA/OAR/ESRL PSD. Retrieved from https://www.esrl.noaa.gov/psd/

Nugues, M. M., Roberts, C. M., 2003. Partial mortality in massive reef corals as an indicator of sediment stress on coral reefs. Marine Pollution Bulletin, 46(3), 314-323.

Nystrom, M., Graham, N. A. J., Lokrantz, J., Norstro"m, A. V., 2008. Capturing the cornerstones of coral reef resilience: linking theory to practice. Coral Reefs, 27(4), 967-974.

Palmer, C. V., Roth, M. S., Gates, R. D., 2009. Red fluorescent protein responsible for pigmentation in trematode-infected Porites compressa tissues. The Biological Bulletin, 216(1), 68-74.

Palmer, S. E., Perry, C. T., Smithers, S. G., Gulliver, P., 2010. Internal structure and accretionary history of a nearshore, turbid-zone coral reef: Paluma Shoals, central Great Barrier Reef, Australia. Marine Geology, 276, 14-29.

Perry, C. T., Larcombe, P., 2003. Marginal and non-reef-building coral environments. Coral Reefs, 22, 427-432.

Peer) reviewing PDF | (2018:10:31951:2:0:ACCEPTED 24 Jun 2019) 
857 Pilcher, N. J., Cabanban, A. S. (2000). The status of coral reefs in Sabah, Labuan and Sarawak, $858 \quad$ East Malaysia: Australian Institute of Marine Science.

859 Pollock, F. J., Lamb, J. B., Field, S. N., Heron, S. F., Schaffelke, B., Shedrawi, G., Bourne, D.

860

861

862

863

864

865

866

867

868

869

870

871

872

873

874

875

876

877

878

879

880

881

882

883

884

885

886

887

888

889

890

891

892

893

894

895

896

897

898

899

900

901 G., Willis, B. L., 2014. Sediment and turbidity associated with offshore dredging increase coral disease prevalence on nearby reefs. PLOS ONE, 9(7), e102498.

Pratchett, M. S., 2005. Dietary overlap among coral-feeding butterflyfishes (Chaetodontidae) at Lizard Island, northern Great Barrier Reef. Marine Biology, 148(2), 373-382.

Pratchett, M. S., McCowan, D., Maynard, J. A., Heron, S. F., 2013. Changes in bleaching susceptibility among corals subject to ocean warming and recurrent bleaching in Moorea, French Polynesia. PLOS ONE, 8(7), e70443.

Praveena, S. M., Siraj, S. S., Aris, A. Z., 2012. Coral reefs studies and threats in Malaysia: a mini review. Reviews in Environmental Science and Bio/Technology, 11(1), 27-39.

Prouty, N. G., Cohen, A., Yates, K. K., Storlazzi, C. D., Swarzenski, P. W., White, D., 2017. Vulnerability of coral reefs to bioerosion from land-based sources of pollution. Journal of Geophysical Research: Oceans. Oceans 122(12), 9319-9331.

Raymundo, L. J., Rosell, K. B., Reboton, C. T., Kaczmarsky, L., 2005. Coral diseases on Philippine reefs: genus Porites is a dominant host. Diseases of aquatic organisms, 64(3), 181-191.

Reef Check Malaysia (2010). Status of coral reefs in Malaysia. Retrieved from

http://www.reefresilience.org/wp-content/uploads/RCMSUR 2010.pdf

Reef Check Malaysia. (2014). Status of coral reefs in Malaysia. Retrieved from ftp://ftp.nodc.noaa.gov/pub/data.nodc/coris/library/NOAA/Non-CRCP/Corals/20150320 RCM Survey Report 2014.pdf

Richards, Z. T., Garcia, R. A., Wallace, C. C., Rosser, N. L., Muir, P. R., 2015. A diverse assemblage of reef corals thriving in a dynamic intertidal reef setting (Bonaparte Archipelago, Kimberley, Australia). PLOS ONE, 10(2), e0117791.

Riegl, B., Branch, G. M., 1995. Effects of sediment on the energy budgets of four scleractinian (Bourne 1900) and five alcyonacean (Lamouroux 1816) corals. Journal of Experimental Marine Biology and Ecology, 186, 259-275.

Risk, J. A., Sammarco, P. W., 1991. Cross-shelf trends in skeletal density of the massive coral Porites lobata from the Great Barrier Reef. Marine Ecology Progress Series, 69, 195-200.

Rogers, C. S., 1983. Sublethal and lethal effects of sediments applied to common Caribbean reef corals in the field. Marine Pollution Bulletin, 14(10), 378-382.

Rogers, C. S., 1990. Responses of coral reefs and reef organisms to sedimentation Marine Ecology Progress Series, 62, 185-202.

Rogers, C. S., Miller, J., 2006. Permanent 'phase shifts' or reversbile declines in coral cover? Lack of recovery of two coral reefs in St. John, US Virgin Islands. Marine Ecology Progress Series, 306, 103-114.

Roy, K. J., Smith, S. V., 1971. Sedimentation and coral reef development in turbid water: Fanning Lagoon. Pacific Science, 25, 234-248.

Shabdin, M. L., 2014. Sarawak coastal biodiversity: A current status. Kuroshio Science, 8(1), 7184.

Stimson, J., Sakai, K., Sembali, H., 2002. Interspecific comparison of the symbiotic relationship in corals with high and low rates of bleaching-induced mortality. Coral Reefs, 21(4), 409421. 
902 Syvitski, J. P., Vörösmarty, C. J., Kettner, A. J., Green, P., 2005. Impact of humans on the flux 903 of terrestrial sediment to the global coastal ocean. science, 308(5720), 376-380.

904

905

906

907

908

909

910

911

912

913

914

915

916

917

918

919

920

921

922

923

924

925

926

927

928

929

930

931

932

933

934

935

936

937

938

939

940

941

942

943
Teh, L., Cabanban, A. S., 2007. Planning for sustainable tourism in southern Pulau Banggi: An assessment of biophysical conditions and their implications for future tourism development. Journal of Environmental Management, 85(4), 999-1008.

Teh, L., Teh, L. (2014). Reconstructing the marine fisheries catch of Peninsular Malaysia, Sarawak and Sabah, 1950-2010. Fisheries Centre Working paper.

Tribollet, A., Aeby, G., Work, T., 2011. Survey and determination of coral and coralline algae diseases/lesions in the lagoon of New Caledonia. Scientific Report. COMPONENT 3DProject 3D3 Studies of coral diseases in New Caledonia. CRISP. New Caledonia.

Tudhope, A. W., Scoffin, T. P., 1994. Growth and structure of fringing reefs in a muddy environment, South Thailand. Journal of Sedimentary Research, 64(4a), 752-764.

Turak, E., DeVantier, L., 2010. Marine tourism, coral biodiversity and conservation priorities in El Nido, Palawan. El Nido Foundation, Phillipines Final Report to El Nido Foundation.

Voss, J. D., Richardson, L. L., 2006. Nutrient enrichment enhances black band disease progression in corals. Coral Reefs, 25(4), 569-576.

Vroom, P. S., 2011. "Coral dominance": a dangerous ecosystem misnomer? Journal of Marine Biology, 2011. Article ID 164127.

Waheed, Z., van Mil, H. G. J., Syed Hussein, M. A., Jumin, R., Golam Ahad, B., Hoeksema, B. W., 2016. Coral reefs at the northernmost tip of Borneo: An assessment of scleractinian species richness patterns and benthic reef assemblages. PLOS ONE, 10(12), e0146006.

Weber, M., Lott, C., Fabricius, K. E., 2006. Sedimentation stress in a scleractinian coral exposed to terrestrial and marine sediments with contrasting physical, organic and geochemical properties. Journal of Experimental Marine Biology and Ecology, 336(1), 18-32.

Wesseling, I., Uychiaoco, A. J., Aliño, P. M., Vermaat, J. E., 2001. Partial mortality in Porites corals: variation among Philippine reefs. International Review of Hydrobiology: A Journal Covering all Aspects of Limnology and Marine Biology, 86(1), 77-85.

Wilkinson, C., 2006. Status of coral reefs of the world: summary of threats and remedial action. Coral reef conservation, 3-39.

Willis, B. L., Page, C. A., Dinsdale, E. A. (2004). Coral disease on the great barrier reef. In Coral health and disease (pp. 69-104): Springer.

Wolanski, E., Fabricius, K., Spagnol, S., Brinkman, R., 2005. Fine sediment budget on an innershelf coral-fringed island, Great Barrier Reef of Australia. Estuarine, Coastal and Shelf Sciences, 65, 153-158.

Woolridge, S. (2008). Regional scale coral bleaching predictions for the Great Barrier Reef (1990 - 2050). Townsville: Australian Institute of Marine Science.

World Wide Weather (2017) https://www.worldweatheronline.com/miri-weatheraverages/sarawak/my.aspx.

Xu, L., Yu, K., Li, S., Liu, G., Tao, S., Shi, Q., Chen, T., Zhang, H., 2017. Interseasonal and interspecies diversities of Symbiodinium density and effective photochemical efficiency in five dominant reef coral species from Luhuitou fringing reef, northern South China Sea. Coral Reefs, 36(2), 477-487. 
Figure 1

Map of south China Sea with enlarged map of study area, showing locations of the three reefs, Miri city and the closest rivers.

(Image credit Hedwig Krawczyk modified from Natural Earth - Free vector and raster map data).

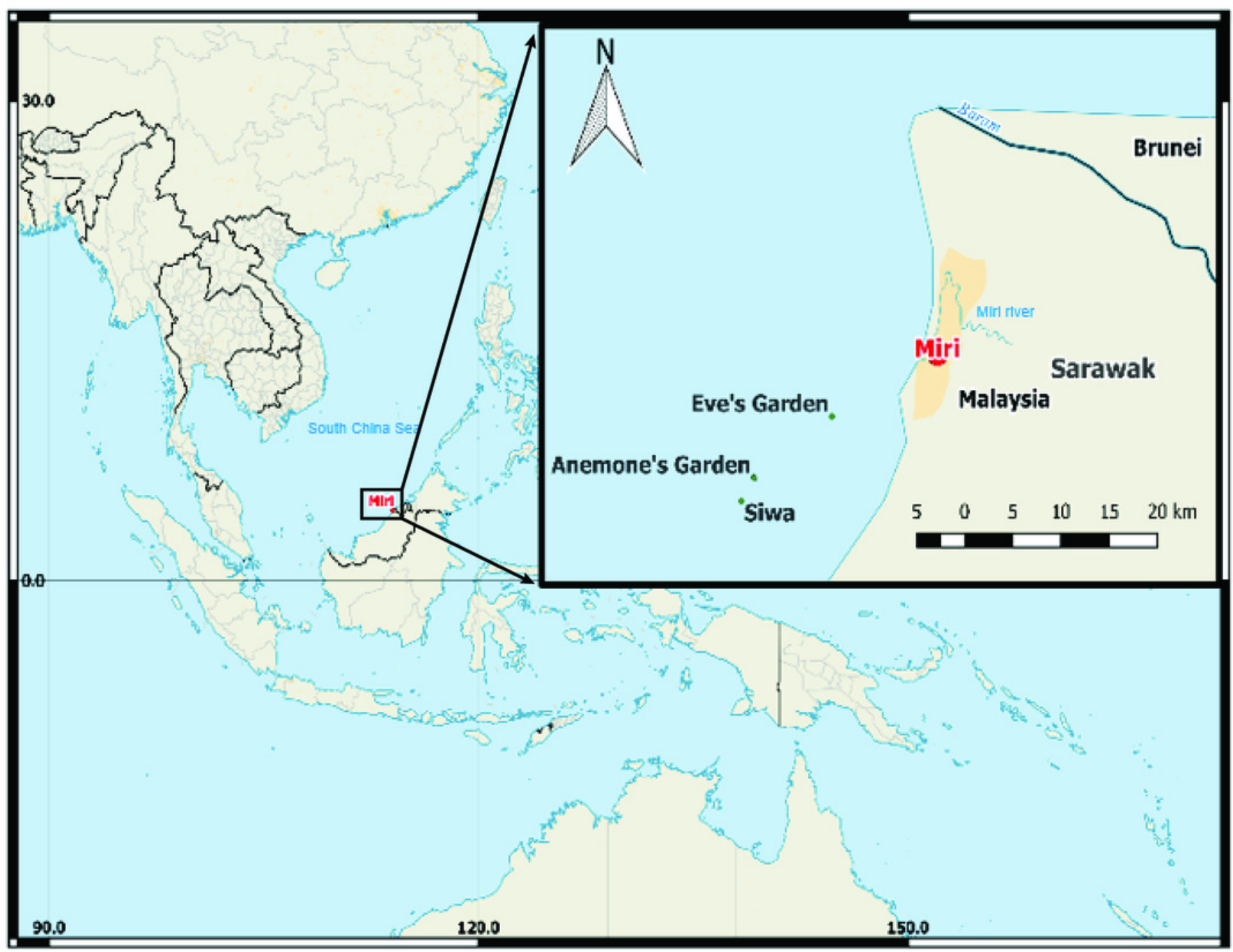


Figure 2

Average monthly data for A. light, B. wind speeds, C. cloud cover, and D. rain fall.

Light data was collected at EG as part of this study whereas wind, cloud and cover data was taken from the worldwideweatheronline.com website (error bars $=\mathrm{SE}$ ). 

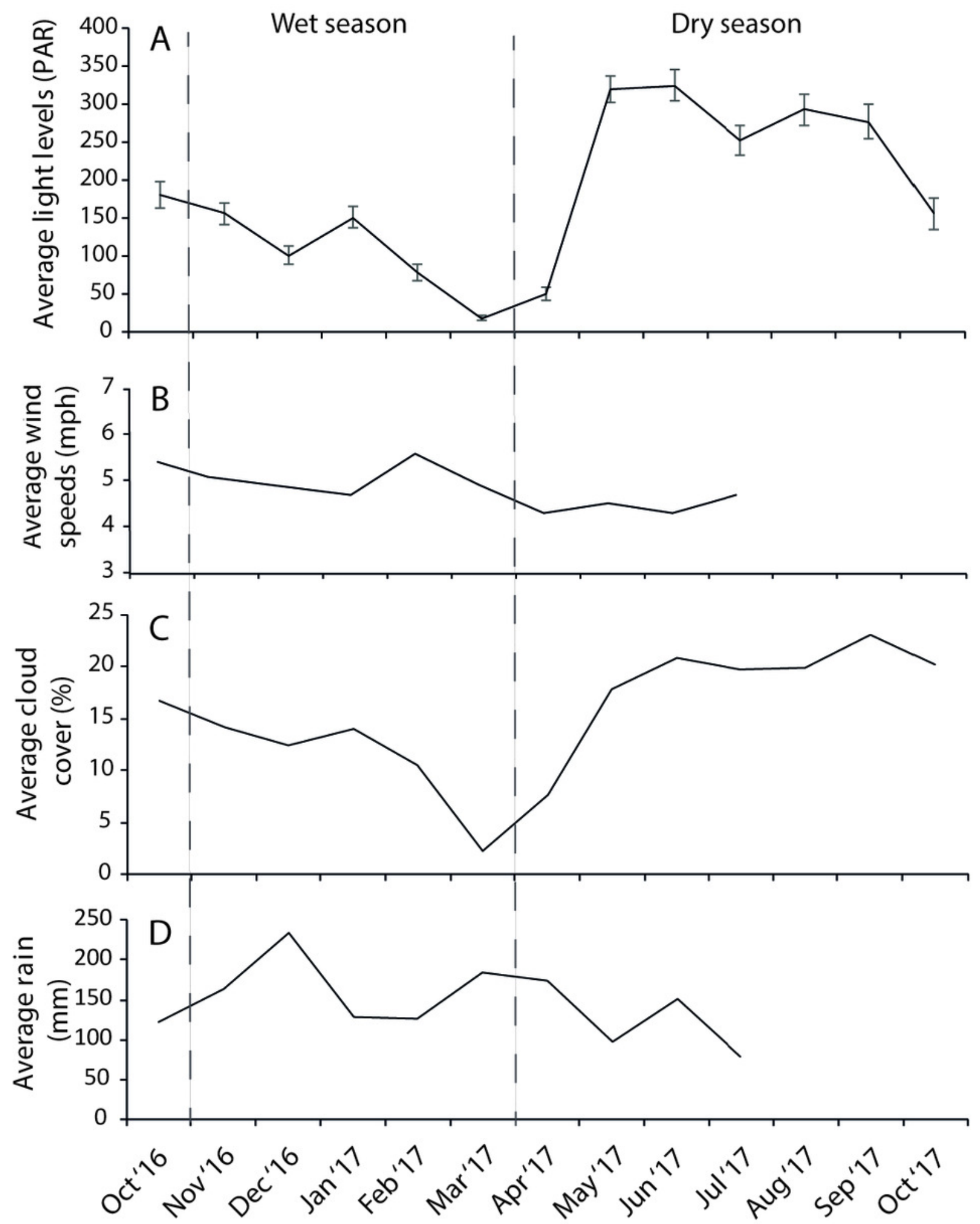
Figure 3

Average sedimentation rates at the three surveyed sites (error bars $=\mathrm{SE}$ ).

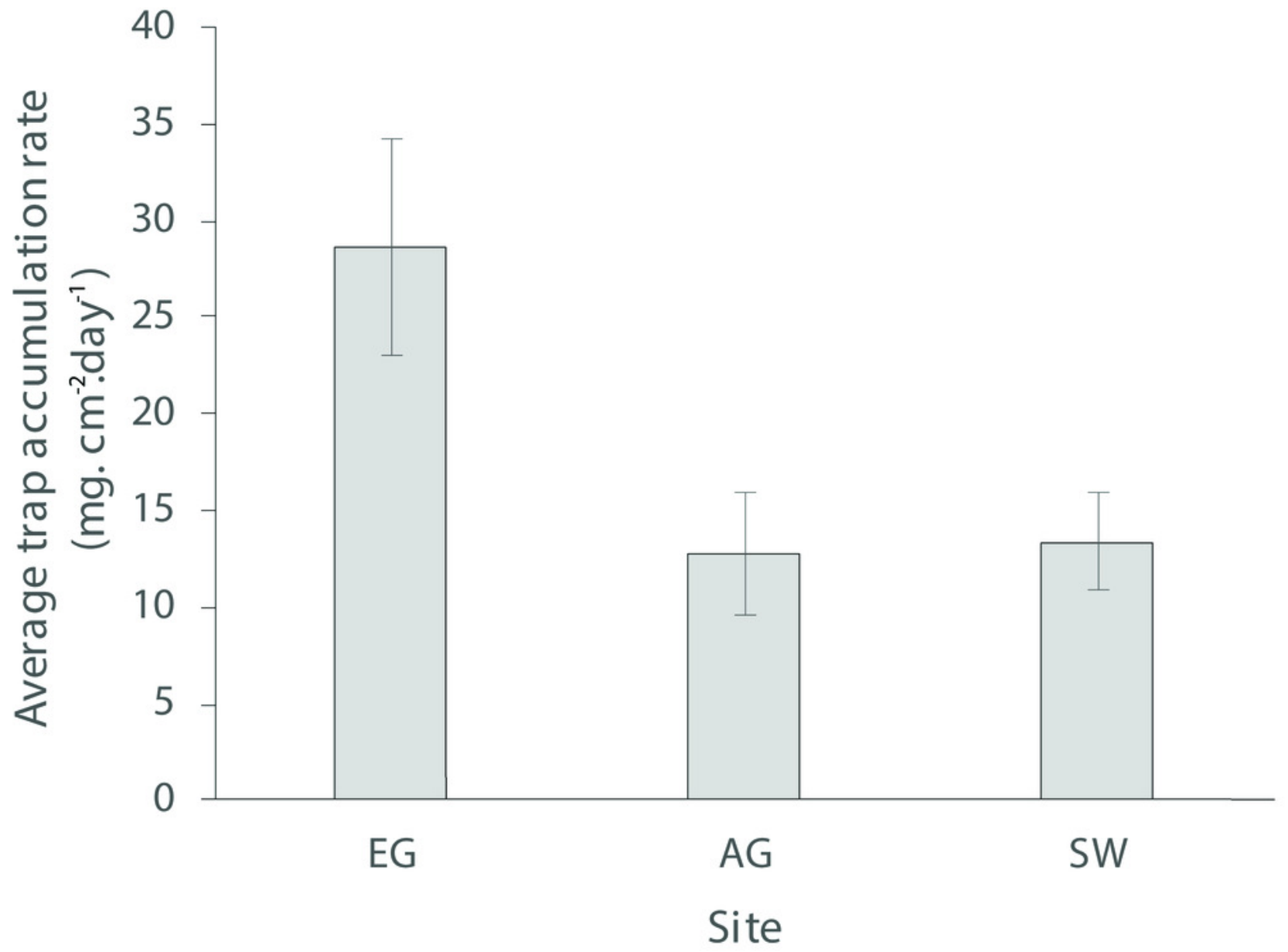


Figure 4

Particle size data from the sediment traps and the benthos at EG, AG and SW.

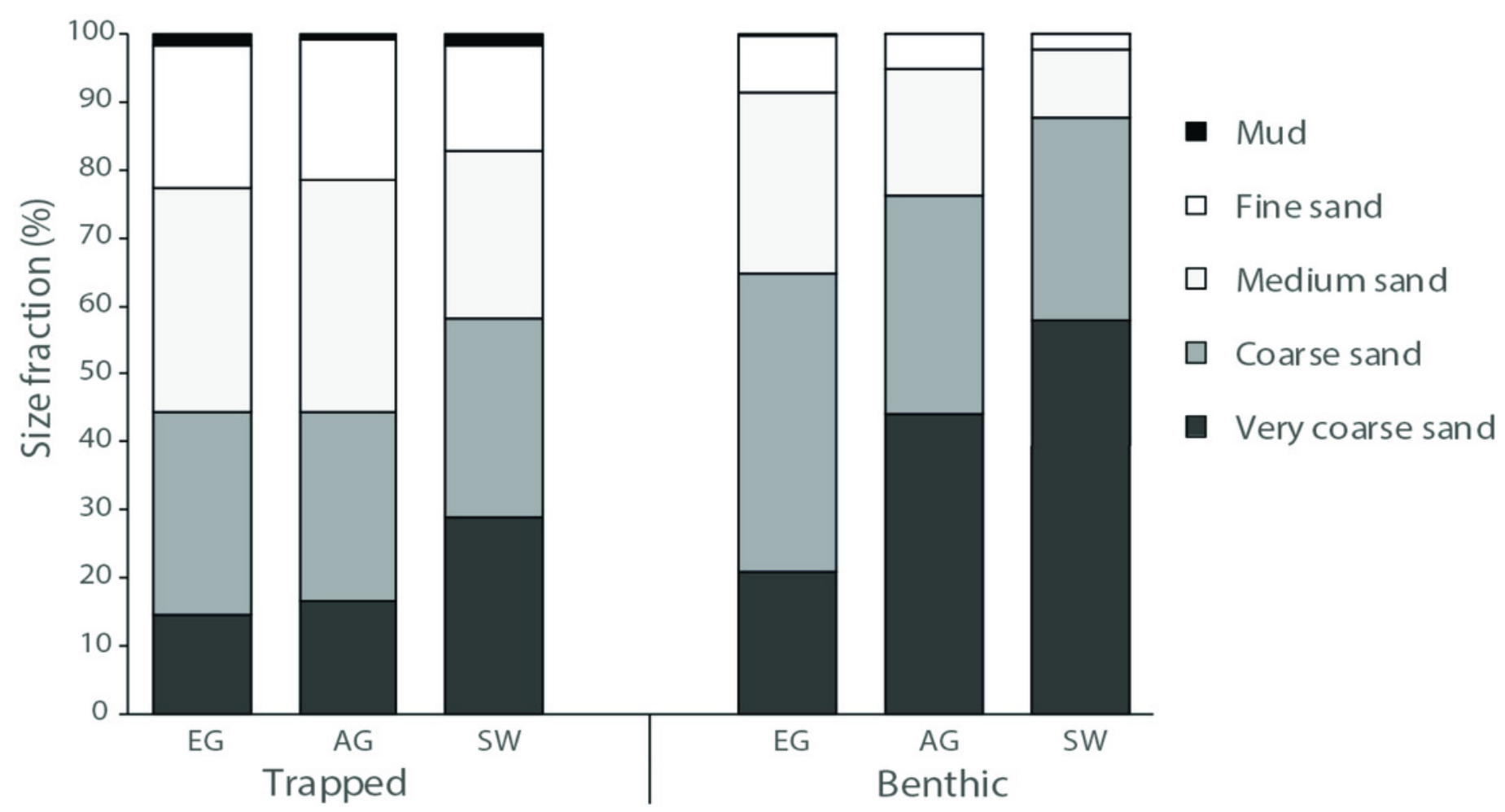


Figure 5

Average percentage benthic cover at EG, AG and SW. Sites are organised from inshore to offshore (error bars $=\mathrm{SE}$ ).

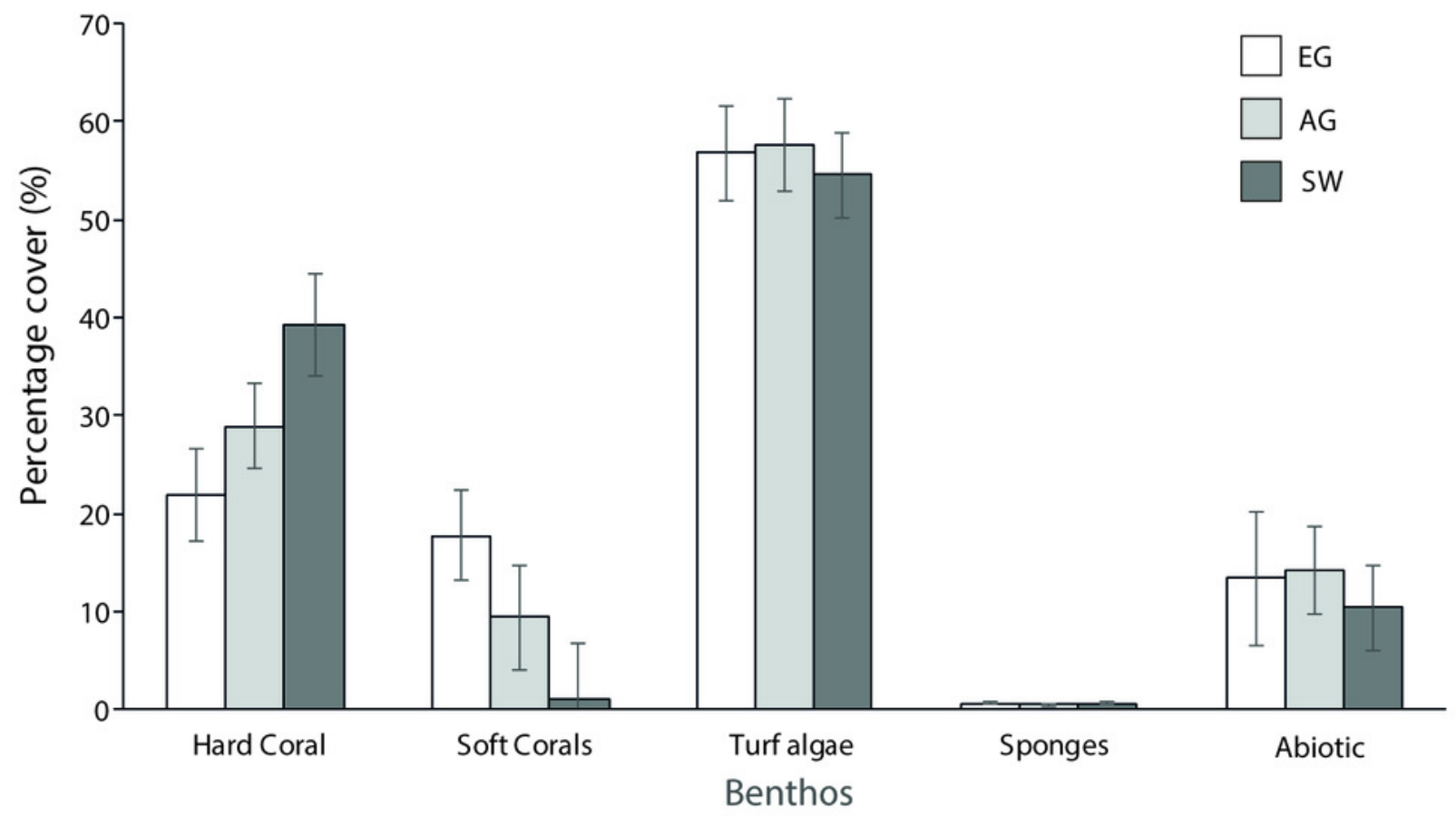




\section{Figure 6}

Signs of impaired health

A. Excessive mucus and slothing, B. Feeding scars from parrotfish, C. Christmas tree worms and bivalves, D. pigmentation response in Porites sp. E. Non-focal bleaching, and F. Partial bleaching. Black arrow points to associated impaired health sign

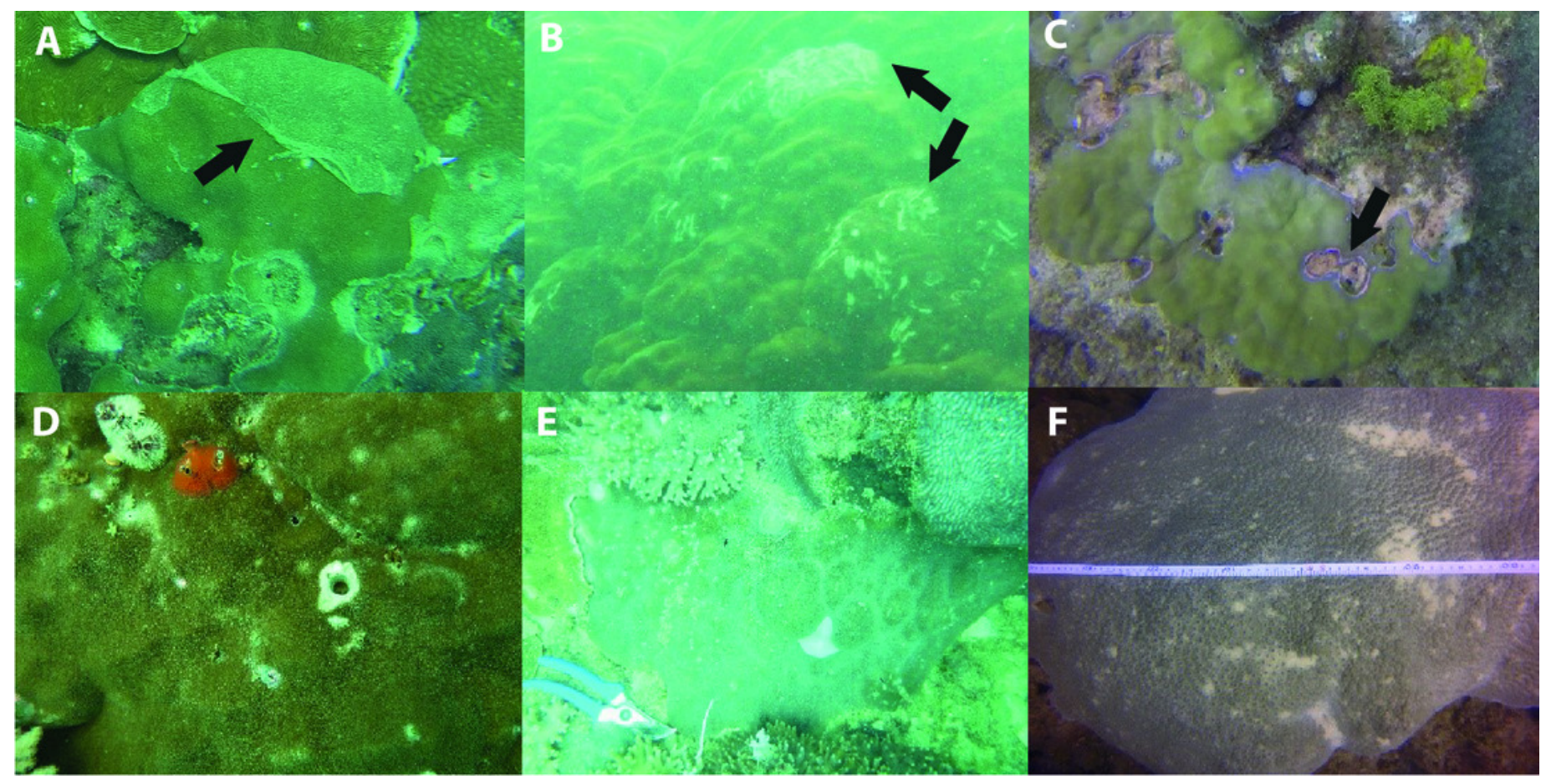


Figure 7

Average prevalence of the dominant signs of impaired health across all three surveyed sites (EG, AG, SW) following the 2016 dry season and 2017 wet season (error bars = SE).

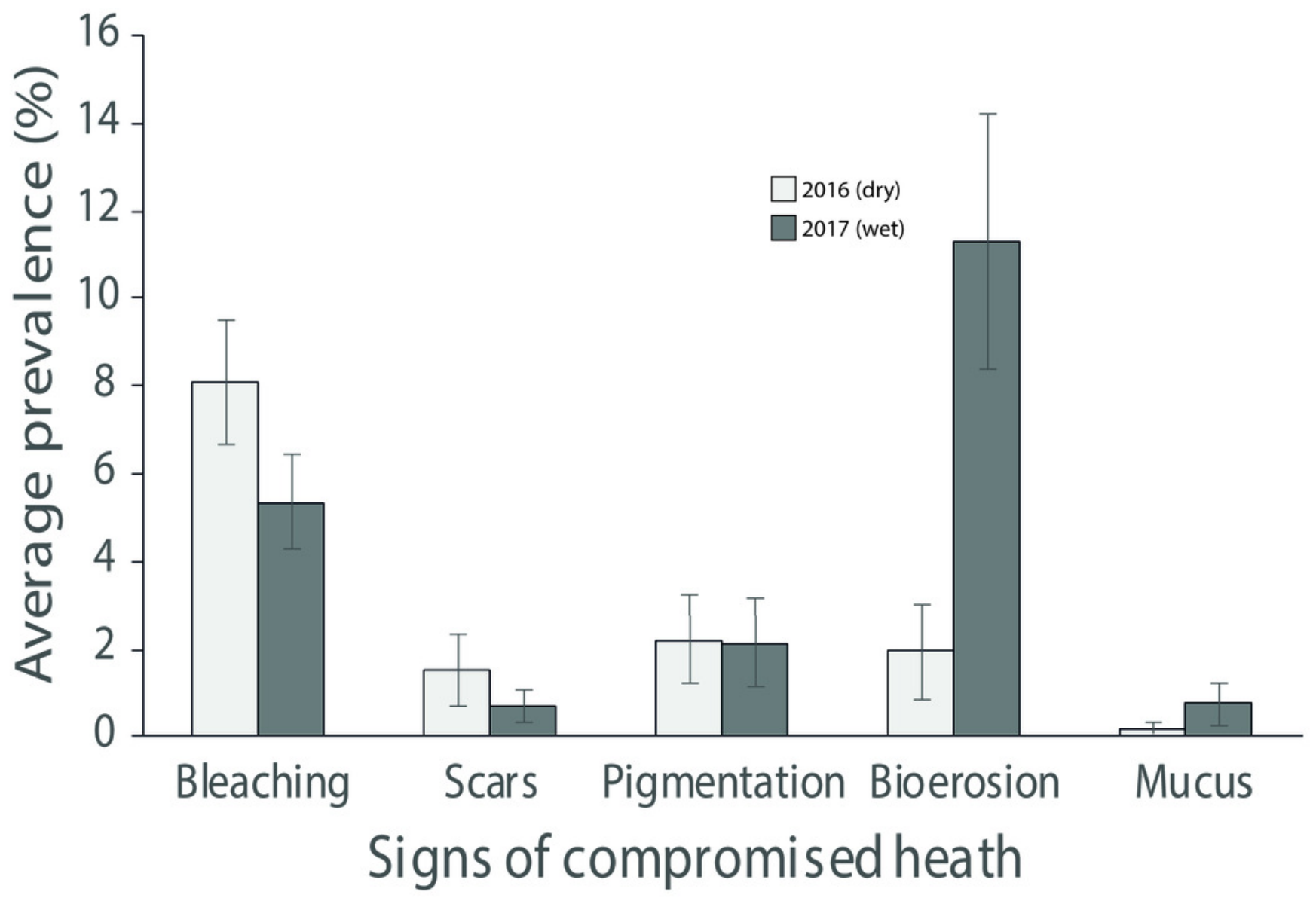


Figure 8

Average bleaching scale for the three coral genus across the three survey sites (EG, AG, SW) that were tagged in September 2016 following the warm dry season and cooler wet season (error bars $=\mathrm{SE}$ ).

( $1=$ normal, $2=$ pale, $3=0-20 \%$ bleached, $3=21-50 \%$ bleached, $4=51-80 \%$ bleached, $5=81-100 \%$ bleached)

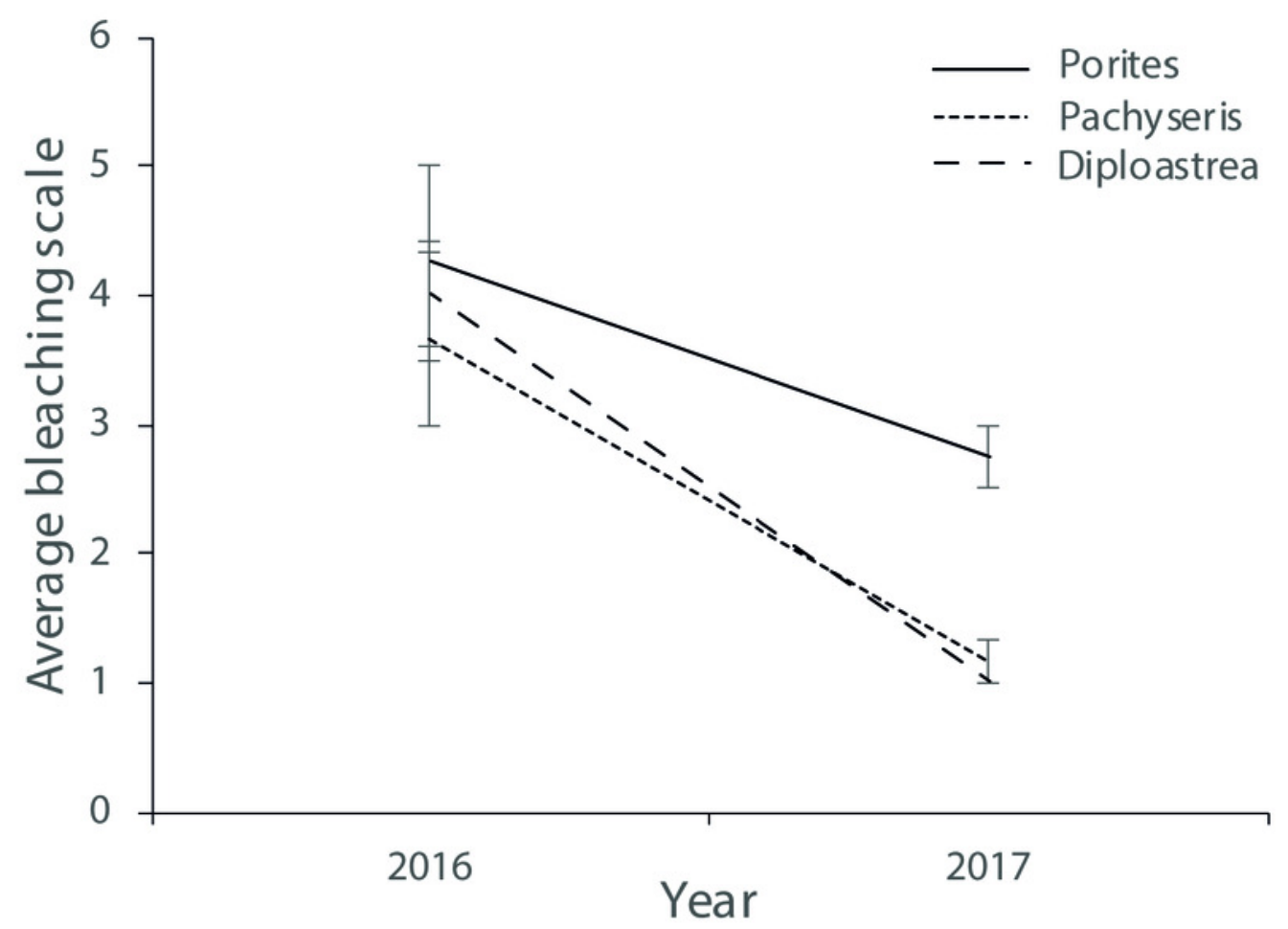


Figure 9

Prevalence of the most common impaired health signs following the 2016 dry season and the 2017 wet season for the five most common observed coral genus across all three sites surveyed (EG, $A G<S W)$.

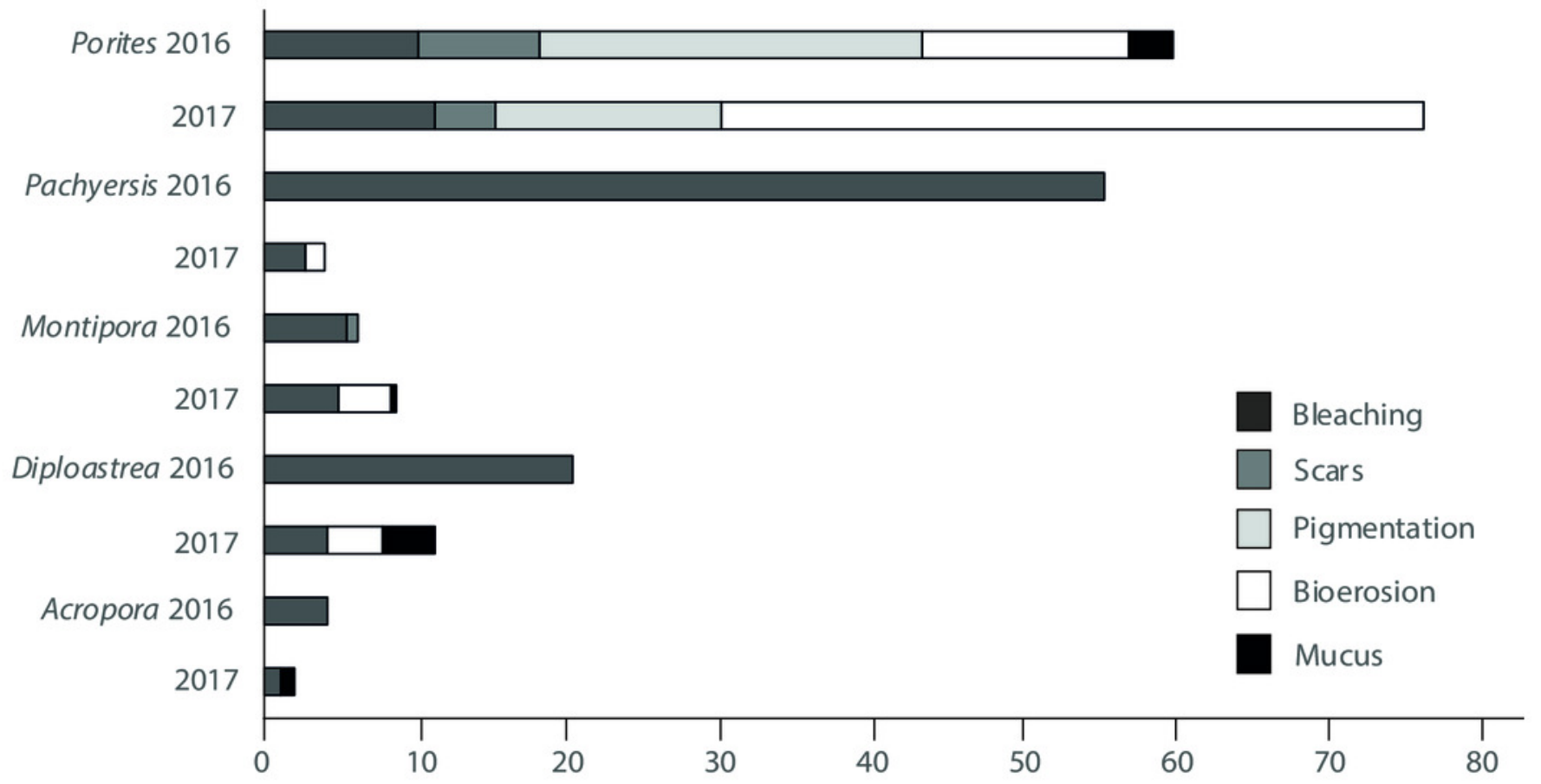


Figure 10

Average symbiont density (A) and chlorophyll a pigment density (B) across the three coral species assessed (Acropora, Monitpora and Pachyseris) at EG, AG and SW (error bars $=\mathrm{SE}$ ).
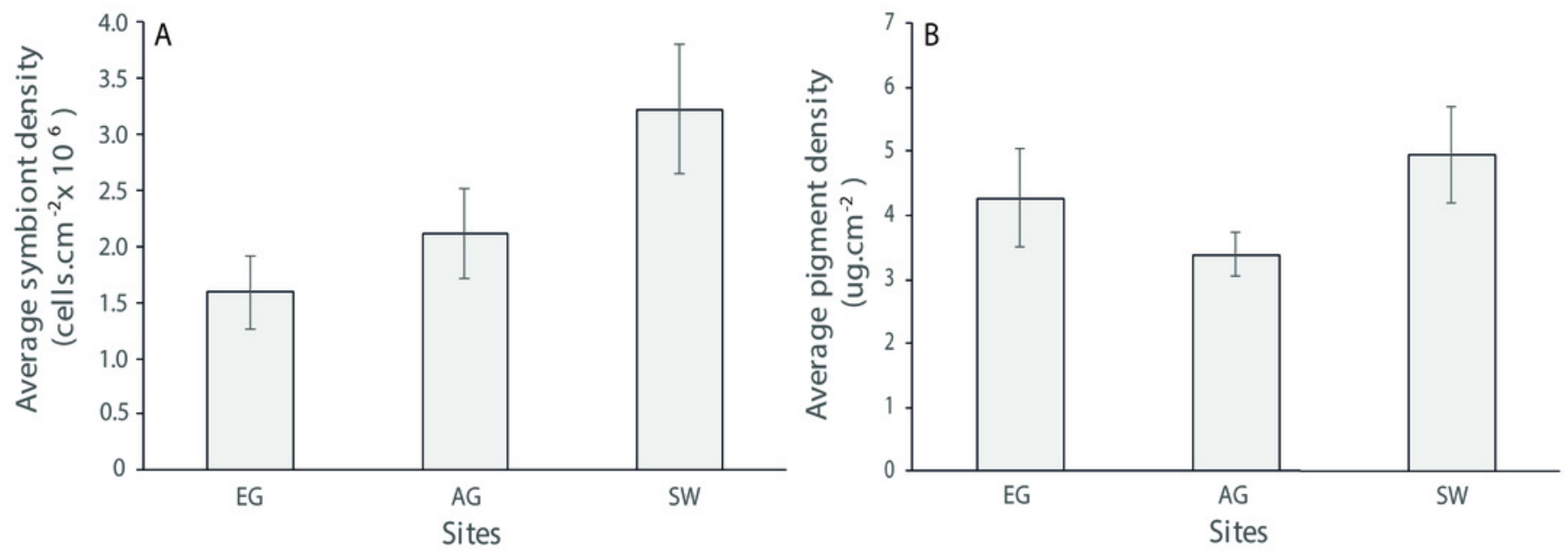
Figure 11

Distance-based redundancy analysis (dbRDA) plot with an AIC criterion selection illustrating the significant environmental factors $(p<0.05)$ that influence community composition at EG, AG and SW.

The length and direction of the vectors represent the strength of the correlation (circle denotes a correlation of 1 ) and direction (+/-) of the relationship with transects (points plotted) at each site.

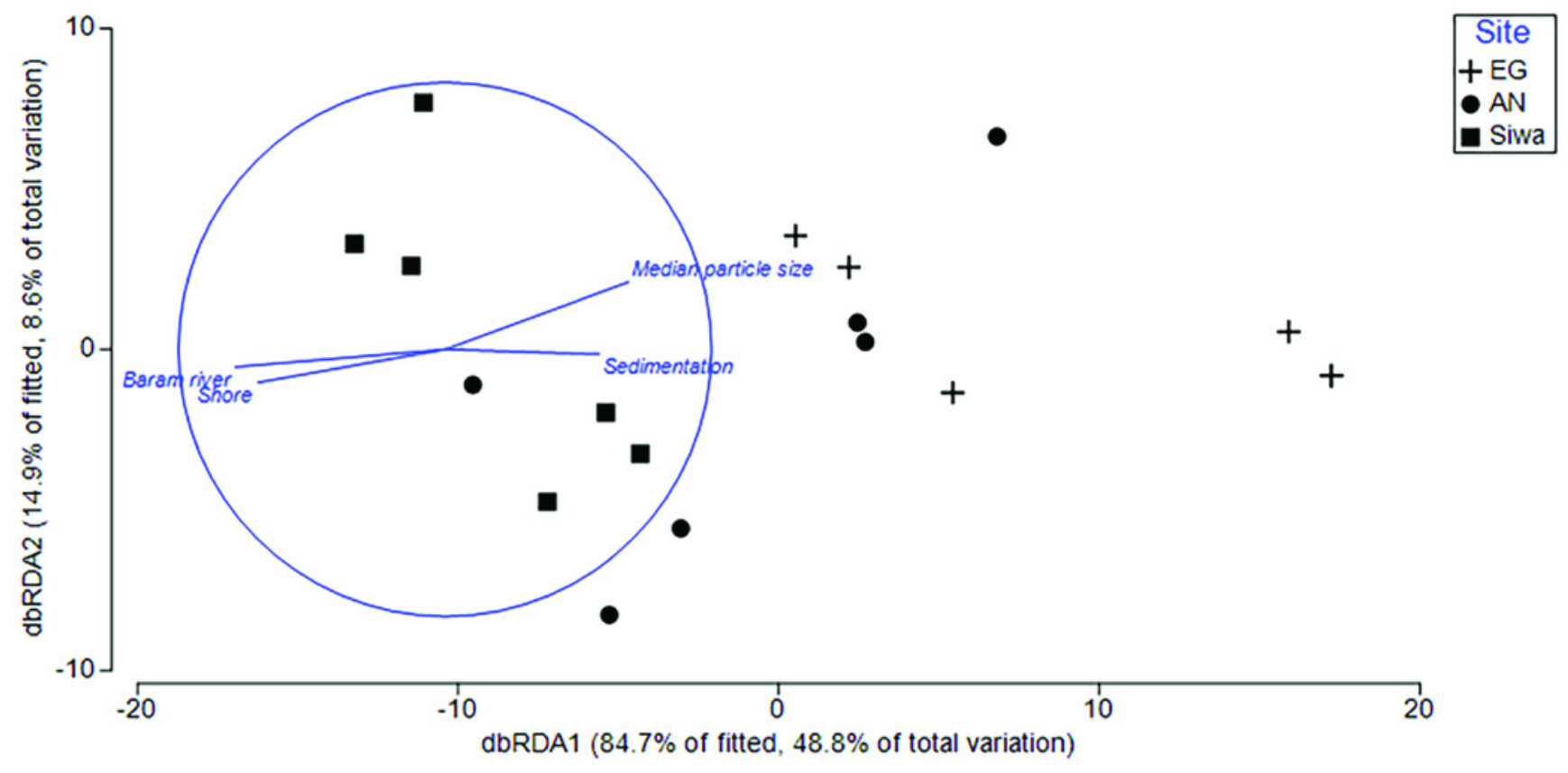




\section{Figure 12}

Distance-based redundancy analysis (dbRDA) plot with an AIC criterion selection illustrating the that influence coral health at at EG, AG and SW.

Significant explanatory variables $(p<0.05 ; \mathrm{HCC}=$ hard coral cover, diversity $=$ coral diversity, year = Sept 2016 and May 2017). The length and direction of the vectors represent the strength and direction (+/-) of the relationship with transects (points plotted) at each site. (Image credit: Amitay Moody).

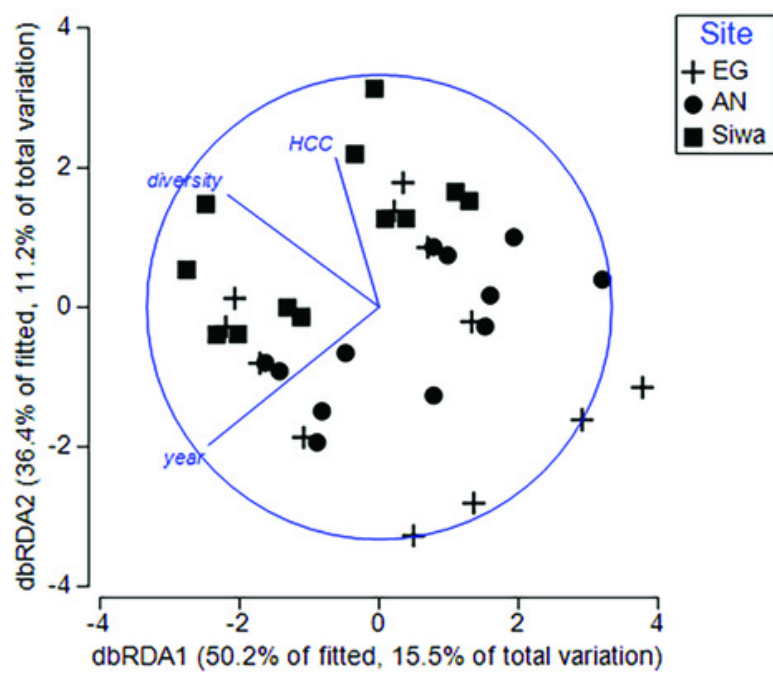




\section{Table $\mathbf{1}$ (on next page)}

Average (\%) coral cover of the 28 genera observed at the three surveyed reefs illustrating the 10 most dominant coral genus. 


\begin{tabular}{|c|c|c|c|}
\hline Genus & Eve's Garden & Anemone's Garden & Siwa reef \\
\hline Acropora (branching) & $0.07 \pm 0.07$ & & $2.60 \pm 0.40$ \\
\hline Diploastrea (massive) & $14.80 \pm 1.60$ & $10.60 \pm 3.70$ & $0.40 \pm 0.10$ \\
\hline Echinopora (encrusting) & & $0.50 \pm 0.14$ & $1.90 \pm 1.60$ \\
\hline Dipsastrea & $0.90 \pm 0.30$ & $3.44 \pm 0.40$ & $3.60 \pm 2.00$ \\
\hline Favites (massive) & $1.70 \pm 0.80$ & $2.40 \pm 0.86$ & $5.10 \pm 1.60$ \\
\hline Galaxea & $3.00 \pm 1$ & $0.62 \pm 0.20$ & $0.90 \pm 0.30$ \\
\hline Merulina & $1.60 \pm 1.5$ & $0.10 \pm 0.03$ & $1.33 \pm 0.80$ \\
\hline Montipora (plate) & $1.30 \pm 100$ & $2.09 \pm 1.10$ & $8.60 \pm 3.00$ \\
\hline Pachyseris (plate) & $2.10 \pm 1.10$ & $0.50 \pm 0.30$ & $2.00 \pm 1.30$ \\
\hline Porites (massive/plate) & $5.70 \pm 2.80$ & $7.30 \pm 1.50$ & $7.30 \pm 2.30$ \\
\hline Astreopora & & & $0.90 \pm 0.60$ \\
\hline Caulastrea & & $0.07 \pm 0.19$ & $0.04 \pm 0.04$ \\
\hline Ctenactis (solitary) & $0.07 \pm 0.07$ & $0.62 \pm 0.15$ & $0.14 \pm 0.09$ \\
\hline Echinophyllia & $0.30 \pm 0.30$ & & $0.06 \pm 0.06$ \\
\hline Fungia & & & $0.10 \pm 0.01$ \\
\hline Goniastrea & & $0.10 \pm 0.03$ & $0.04 \pm 0.04$ \\
\hline Goniopora & $0.03 \pm 0.03$ & & \\
\hline Heliofungia & $0.10 \pm 0.10$ & & \\
\hline Leptoria & $0.03 \pm 0.03$ & & $0.08 \pm 0.08$ \\
\hline Leptoseris & $0.17 \pm 0.17$ & & $1.60 \pm 1.50$ \\
\hline Montastrea & & & $0.04 \pm 0.04$ \\
\hline Oxypora & $0.03 \pm 0.03$ & & $0.17 \pm 0.17$ \\
\hline Pectinia & & & $0.08 \pm 0.08$ \\
\hline Physogyra & & & $0.17 \pm 0.17$ \\
\hline Platygyra (massive) & $0.90 \pm 0.80$ & $1.79 \pm 1.60$ & $0.60 \pm 0.40$ \\
\hline Psammocora & $0.10 \pm 0.10$ & & \\
\hline Symphyllia & & $0.40 \pm 0.20$ & $0.69 \pm 0.30$ \\
\hline Turbinaria & & & $0.68 \pm 0.68$ \\
\hline
\end{tabular}




\section{Table 2 (on next page)}

Statistical results from two-way ANOVA of the total impaired health and each impaired health indicator with site ( $E G=$ Eves Garden, $A G=$ Anenomes Garden, SW = Siwa) and season $(2016,2017)$, and the interaction. 


\begin{tabular}{|c|c|c|c|c|c|}
\hline Health sign & Factor & df & F value & p value & Post hoc \\
\hline \multirow{3}{*}{$\begin{array}{l}\text { Total impaired } \\
\text { health }\end{array}$} & Site & 2 & 0.25 & 0.780 & \\
\hline & Season & 1 & 1.11 & 0.300 & \\
\hline & Site*Season & 2 & 0.15 & 0.860 & \\
\hline \multirow[t]{3}{*}{ Bleaching } & Site & 2 & 0.19 & 0.830 & \\
\hline & Season & 1 & 3.30 & 0.080 & \\
\hline & Site*Season & 2 & 0.69 & 0.510 & \\
\hline \multirow[t]{3}{*}{ Mucus } & Site & 2 & 3.60 & 0.040 & $\mathrm{EG}<\mathrm{AG}, \mathrm{SW}$ \\
\hline & Season & 1 & 0.15 & 0.700 & \\
\hline & Site*Season & 2 & 7.20 & 0.003 & \\
\hline \multirow[t]{3}{*}{ Bioerosion } & Site & 2 & 0.87 & 0.430 & \\
\hline & Season & 1 & 20.20 & $<0.001$ & $2017>2016$ \\
\hline & Site*Season & 2 & 3.80 & 0.040 & \\
\hline \multirow[t]{3}{*}{ Pimentation } & Site & 2 & 5.30 & 0.010 & $\mathrm{AG}>\mathrm{SW}$ \\
\hline & Season & 1 & 1.00 & 0.320 & \\
\hline & Site*Season & 2 & 0.82 & 0.440 & \\
\hline \multirow[t]{3}{*}{ Scars } & Site & 2 & 0.10 & 0.910 & \\
\hline & Season & 1 & 0.33 & 0.570 & \\
\hline & Site*Season & 2 & 2.59 & 0.090 & \\
\hline
\end{tabular}

1 


\section{Table 3 (on next page)}

Statistical results from two-way ANOVA of the total impaired health and each impaired health indicator for the 5 most dominant coral genera with site and season and the interaction.

If impaired health result is missing then it was not observed for that coral genus. Sites; EG = Eves Garden, AG = Anenomes Garden, SW = Siwa: Seasons; 2016, 2017. 


\begin{tabular}{|c|c|c|c|c|c|c|}
\hline Species & Health sign & Factor & df & F value & p value & Post hoc \\
\hline \multirow[t]{18}{*}{ Porites } & \multirow[t]{3}{*}{ Total } & Site & 2 & 1.71 & 0.202 & \\
\hline & & Year & 1 & 10.17 & 0.004 & $2017>2016$ \\
\hline & & Site*year & 2 & 4.00 & 0.031 & \\
\hline & \multirow[t]{3}{*}{ Bleaching } & Site & 2 & 0.36 & 0.701 & \\
\hline & & Year & 1 & 0.08 & 0.774 & \\
\hline & & Site*year & 2 & 1.81 & 0.185 & \\
\hline & \multirow[t]{3}{*}{ Mucus } & Site & 2 & 6.72 & 0.034 & $\mathrm{EG}>\mathrm{SW}$ \\
\hline & & Year & 1 & 2.64 & 0.104 & \\
\hline & & Site*year & & & & \\
\hline & \multirow[t]{3}{*}{ Bioerosion } & Site & 2 & 1.61 & 0.219 & \\
\hline & & Year & 1 & 21.79 & $<0.001$ & $2017>2016$ \\
\hline & & Site*year & 2 & 6.29 & 0.006 & \\
\hline & \multirow{3}{*}{ Pimentation } & Site & 2 & 8.79 & 0.001 & $\mathrm{Eg}, \mathrm{AG}>\mathrm{SW}$ \\
\hline & & Year & 1 & 2.49 & 0.128 & \\
\hline & & Site*year & 2 & 2.09 & 0.145 & \\
\hline & \multirow[t]{3}{*}{ Scars } & Site & 2 & 0.46 & 0.637 & \\
\hline & & Year & 1 & 0.38 & 0.543 & \\
\hline & & Site*year & 2 & 2.25 & 0.126 & \\
\hline \multirow[t]{9}{*}{ Pachyseris } & \multirow[t]{3}{*}{ Total } & Site & 2 & 0.30 & 0.744 & \\
\hline & & Year & 1 & 9.02 & 0.008 & $2016>2017$ \\
\hline & & Site*year & 2 & 0.14 & 0.869 & \\
\hline & \multirow[t]{3}{*}{ Bleaching } & Site & 2 & 0.37 & 0.699 & \\
\hline & & Year & 1 & 9.69 & 0.006 & $2016>2017$ \\
\hline & & Site*year & 2 & 0.11 & 0.897 & \\
\hline & \multirow[t]{3}{*}{ Bioerosion } & Site & 2 & 0.49 & 0.622 & \\
\hline & & Year & 1 & 1.42 & 0.249 & \\
\hline & & Site*year & 2 & 0.39 & 0.685 & \\
\hline \multirow[t]{9}{*}{ Montipora } & \multirow[t]{3}{*}{ Total } & Site & 2 & 0.77 & 0.476 & \\
\hline & & Year & 1 & 1.65 & 0.211 & \\
\hline & & Site*year & 2 & 1.45 & 0.254 & \\
\hline & \multirow[t]{3}{*}{ Bleaching } & Site & 2 & 2.06 & 0.149 & \\
\hline & & Year & 1 & 0.29 & 0.594 & \\
\hline & & Site*year & 2 & 0.73 & 0.494 & \\
\hline & \multirow[t]{3}{*}{ Bioerosion } & Site & 2 & 0.83 & 0.449 & \\
\hline & & Year & 1 & 0.83 & 0.371 & \\
\hline & & Site*year & 2 & 0.68 & 0.519 & \\
\hline \multirow[t]{7}{*}{ Diploastrea } & \multirow[t]{3}{*}{ Total } & Site & 2 & 0.66 & 0.527 & \\
\hline & & Year & 1 & 0.10 & 0.752 & \\
\hline & & Site*year & 2 & 2.54 & 0.104 & \\
\hline & \multirow[t]{3}{*}{ Bleaching } & Site & 2 & 0.63 & 0.541 & \\
\hline & & Year & 1 & 1.69 & 0.209 & \\
\hline & & Site*year & 2 & 2.06 & 0.152 & \\
\hline & Mucus & Site & 2 & 0.58 & 0.570 & \\
\hline
\end{tabular}




\begin{tabular}{|c|c|c|c|c|c|}
\hline & \multirow{5}{*}{ Bioerosion } & Year & 1 & 2.75 & 0.113 \\
\hline & & Site*year & 2 & 0.71 & 0.502 \\
\hline & & Site & 2 & 1.64 & 0.220 \\
\hline & & Year & 1 & 0.86 & 0.364 \\
\hline & & Site*year & 2 & 0.99 & 0.391 \\
\hline \multirow[t]{6}{*}{ Acropora } & \multirow[t]{3}{*}{ Total } & Site & 2 & 1.92 & 0.171 \\
\hline & & Year & 1 & 0.22 & 0.644 \\
\hline & & Site*year & 2 & 0.14 & 0.872 \\
\hline & \multirow[t]{3}{*}{ Bleaching } & Site & 2 & 1.27 & 0.300 \\
\hline & & Year & 1 & 1.02 & 0.323 \\
\hline & & Site*year & 2 & 0.64 & 0.538 \\
\hline
\end{tabular}

1 


\section{Table 4 (on next page)}

PERMANOVA results highlighting the significant drivers that explain variation in benthic community assemblage among reefs in 2017 


\begin{tabular}{lccc}
\hline Explanatory variable & p value & Pseudo-F & $\mathbf{R}^{\mathbf{2}}$ \\
\hline \hline Depth & 0.094 & 2.3 & 0.010 \\
Dist. Baram River & $\mathbf{0 . 0 0 2}$ & 7.0 & 0.303 \\
Dist. Shore & $\mathbf{0 . 0 0 7}$ & 5.1 & 0.008 \\
Sedimentation rate & $\mathbf{0 . 0 2 5}$ & 3.9 & 0.023 \\
Course sediments & 0.069 & 2.7 & 0.001 \\
Fine sediments & 0.070 & 2.7 & 0.100 \\
Silt & 0.153 & 1.9 & 0.015 \\
Median particle size & $\mathbf{0 . 0 1 0}$ & 5.0 & 0.164 \\
\hline
\end{tabular}

1 


\section{Table 5 (on next page)}

PERMANOVA results highlighting the significant drivers in coral health.

The top panel are the results of a DistLM that includes substrate structure and physical conditions among reefs and across both sampling seasons, and the bottom panel are the results of a DistLM that includes data from the sediment traps among reefs in 2017 only. 


\begin{tabular}{lccc}
\hline & \multicolumn{3}{c}{ Pseudo- } \\
Explanatory variable & p value & $\mathbf{F}$ & $\mathbf{R}^{\mathbf{2}}$ \\
\hline \hline Year & $\mathbf{0 . 0 0 3}$ & 5.0 & 0.128 \\
HCC & $\mathbf{0 . 0 4 2}$ & 2.8 & 0.052 \\
Diversity & $\mathbf{0 . 0 0 3}$ & 5.1 & 0.129 \\
Dist. Baram River & 0.304 & 1.3 & 0.019 \\
Dist. Shore & 0.521 & 0.8 & 0.020 \\
Depth & 0.467 & 0.9 & 0.017 \\
& & & \\
Sediment variable & $\mathbf{p ~ v a l u e}$ & Pseudo- & \\
\hline Sedimentation rate & 0.059 & 2.4 & $\mathbf{R}^{2}$ \\
Course sediments & $\mathbf{0 . 0 3 1}$ & 2.9 & 0.070 \\
Fine sediments & $\mathbf{0 . 0 3 1}$ & 2.9 & 0.152 \\
Silt & 0.067 & 2.3 & 0.030 \\
Median particle size & 0.083 & 2.2 & 0.110 \\
\hline
\end{tabular}

